\title{
Analiza vpliva vgrajenega sanacijskega materiala na rekultivacijo opuščenega peskokopa
}

\author{
Sonja CERAR ${ }^{1,2}$, Špela BAVEC ${ }^{1}$
}

Received November 4, 2019; accepted December 7, 2019.

Delo je prispelo 04. novembra 2019, sprejeto 07. decembra 2019.

\begin{abstract}
Analiza vpliva vgrajenega sanacijskega materiala na rekultivacijo opuščenega peskokopa

Izvleček: V okviru sanacije opuščenega peskokopa Drtija (Moravče) se kot sanacijski material uporabljajo gradbeni kompoziti, ki se proizvajajo z mešanjem nenevarnih in inertnih odpadkov ter naravnega avtohtonega materiala (kremenov pesek, glina). $\mathrm{V}$ prispevku smo ugotavljali kemično sestavo že vgrajenih sanacijskih materialov ter vpliv le-teh na rekultivacijo površinskih vrhnjih plasti. $V$ ta namen smo z bagrskimi izkopi vzorčili sanacijski material na 3 lokacijah do globine $3 \mathrm{~m}$, okoliška površinska tla $(0-10 \mathrm{~cm})$ na dveh lokacijah ter izcedno vodo na 1 lokaciji. Rezultati kažejo, da so vgrajeni sanacijski materiali obremenjeni s kovinami $(\mathrm{Cd}, \mathrm{Cr}$, $\mathrm{Cu}, \mathrm{Ni}, \mathrm{Pb}, \mathrm{Zn}$ ), ki pa so v danih razmerah slabo topne. Slednje nakazujejo tudi koncentracije kovin v izcedni vodi, ki se pojavljajo znotraj območja spodnje meje določanja (LOQ). Od organskih snovi so v izcedni vodi prisotne povečane vsebnosti fenola in formaldehida, ki pa $v$ sanacijskem materialu nista zaznavna, z izjemo fenola $v$ dveh vzorcih. Vgrajeni sanacijski materiali bodo v sklopu končne sanacije prekriti s plastjo gline in humusa ter zatravljeni ali pogozdeni, zato ugotavljamo, da vpliv sanacijskih materialov na rekultivacijo vrhnje plasti ni pričakovan. Glede na rezultate je najbolj smiselna rekultivacije vrhnje plasti s pogozditvijo.
\end{abstract}

Ključne besede: peskokop kremenovega peska; rekultivacija; sanacija; sanacijski material; Moravče
Impact analysis of inbuilt rehabilitation material on the recultivation of abandoned sandpit

Abstract: For the rehabilitation and reclamation of abandoned sandpit in Drtija (Moravče), construction composites are used as rehabilitation materials. Construction composites are produced by mixing of recycled non-hazardous waste and natural materials. In the presented study, the chemical composition of the rehabilitation materials, which are already built-in on abandoned surfaces and impact analysis on recultivation of the upper layer, was evaluated. For this purpose, the rehabilitation materials were sampled at 3 locations with test pit excavations up to a depth of $3 \mathrm{~m}$, surrounding topsoils $(0-10 \mathrm{~cm})$ at 2 locations and leachate at 1 location. The results show that the in-built rehabilitation materials are burdened with metals $(\mathrm{Cd}, \mathrm{Cr}, \mathrm{Cu}, \mathrm{Ni}, \mathrm{Pb}, \mathrm{Zn})$, which are, however, poorly soluble under the given conditions. The latter is also indicated by the concentrations of metals in the leachate, which are within the lower limit of quantification (LOQ) area. Regarding organic substances, the presence of phenol and formaldehyde was found in the leachate. In rehabilitation materials only phenol was found in two samples. Considering that the rehabilitation materials will be covered with a layer of clay and humus and will be tilled or afforested as part of the final rehabilitation step, the impact of rehabilitation materials on the reclaimed soil is not expected. According to results of this study recultivaton of the upper layer with planting of woods is recommended.

Key words: silica sandpit; recultivation; rehabilitation; rehabilitation material; Moravče 


\section{UVOD}

Destruktivno spreminjanje okolja temelji na prepričanju, da so bistvene sestavine naravnega okolja praktično neizčrpne, a je za kmetijska zemljišča $\mathrm{v}$ zadnjem obdobju mogoče zaslediti opozorila, da je že presežena regeneracijska zmogljivost (Vrščaj, 2010; Pintar in sod., 2010). Obseg kmetijskih zemljišč se zmanjšuje, okoljske zahteve pa se zaostrujejo, zato marsikje v Sloveniji ni več mogoče racionalno kmetovati, še manj pa kmetovati ekološko, saj za to ni dovolj površin. Slovenija je po obsegu kmetijskih obdelovalnih površin (njive in vrtovi) na repu držav članic Evropske unije (Pintar in sod., 2010). S problematiko zmanjšanja kmetijskih zemljišč zaradi tesnjenja tal oziroma odkopi, ki predstavlja globalno grožnjo varnosti preskrbe s hrano in socialni stabilnosti ter biotski raznovrstnosti in ekosistemom pa se srečujejo tudi po svetu (Montanarella, 2017).

Dinamično ravnovesje se lahko poruši ob človekovih posegih, kot npr. površinskih kopih (gramoznice, peskokopi, kamnolomi...), kjer zaradi odvzema mineralnih surovin prihaja do spreminjanja topografije (večje depresije, strma pobočja itd.) (Sharma in sod., 2004). S spremembo režima $\mathrm{v}$ poznih osemdesetih in kasnejšo prilagoditvijo zakonodaje za vstop v Evropsko skupnost je prišlo tudi do sprememb okoljske zakonodaje (Elliot in Udovč, 2005). Velik korak k izboljšanju neravnovesja, povzročenega $\mathrm{v}$ okolju $\mathrm{s}$ površinskimi kopi, je bil narejen s sprejetjem Zakona o rudarstvu (2010), ki je nosilce rudarske pravice zavezal k sanaciji rudarskih prostorov. $\mathrm{Na}$ izkoriščenih površinskih kopih, ki predstavljajo degradirano pokrajino, morajo nosilci rudarske pravice po zaključku izkoriščanja izvesti sanacijska rudarska dela, da se odpravijo posledice, ki so nastale pri izvajanju rudarskih del in izvede dokončna sanacija okolja (96. člen Zakona o rudarstvu (2010)). Površja, ki je bilo izpostavljeno izkopavanju mineralnih surovin, ni mogoče $\mathrm{v}$ celoti vrniti $\mathrm{v}$ prvotno stanje (Grčman in Zupanc, 2018). Degradirano območje se lahko preuredi v sekundarne habitate (Urbanc in Berg, 2005), v športno-rekreacijske površine, deponije komunalnih in drugih odpadkov (Knez in Regent, 1993), izgradnjo rastlinskih čistilnih naprav (Griessler Bulc in Šajn Slak, 2009) ali v kmetijske površine (Krümmelbein in sod., 2010). Pri rekultivaciji degradiranega območja za kmetijsko rabo želimo čas, ki ga naravna sukcesija potrebuje, bistveno skrajšati. Z ukrepi nekatere procese pospešimo, npr. vnos hranil, predvsem dušika (Čop in sod., 2009); nekatere, kot je spiranje nitrata in drugih onesnažil, ublažimo (Laner in sod., 2011), zmanjšamo toksičnost tal (Grčman in sod., 2001), z ozelenitvijo izboljšamo strukturo tal in zmanjšamo nevarnost erozije
(Zupanc in Grčman, 2016). Pri izvedbi rekultivacije površinskega kopa $\mathrm{v}$ kmetijsko površino je zelo pomembno, da nosilec rudarske pravice že $\mathrm{v}$ naprej načrtuje, $\mathrm{v}$ kakšno kmetijsko površino bo površinski kop rekultiviran, ali bo to njiva, travnik, pašnik, gozd itd., in se temu primerno loti načrtovanja ter izvajanja rekultivacije. $\mathrm{V}$ nasprotnem primeru prihaja do slabega izvajanja in $s$ tem posledično do otežene uporabe zemljišča (Škornik Grdina, 2016).

V Sloveniji se je v letu 2018 izkoriščalo 25 mineralnih surovin na skupno 180 nahajališčih, ki zajemajo skupno 206 pridobivalnih prostorov s koncesijsko pogodbo (rudarsko pravico za izkoriščanje) (Senegačnik in sod., 2019). Med slednjimi je tudi družba Termit d. d., ki je pričela $\mathrm{z}$ izkoriščanjem kremenovega peska že leta 1960 in se še danes ukvarja s proizvodnjo in predelavo kremenovih peskov ter izdelavo pomožnih livarskih sredstev za livarne in železarne. Ocena družbe Termit d. d. iz leta 2004 je pokazala, da je potrebno sanirati 2 milijona $\mathrm{m}^{3}$ opuščenih kopov (Pavlin in sod., 2018) oz. približno 20 ha površin (Vajović in sod., 2016). Sanacija z naravnimi materiali ni prišla $\mathrm{v}$ poštev, saj bi s tem ustvarili nova degradirana območja drugje. Zaradi slednjega so $\mathrm{v}$ podjetju pričeli $\mathrm{z}$ reciklažo industrijskih odpadkov v gradbene kompozite, ki so skladni s Slovenskim tehničnim soglasjem (STS). Gradbena industrija spada med največje porabnike naravnih materialov, zato igra pomembno vlogo pri reciklaži odpadkov v gradbene surovine za doseganje trajnostnega razvoja (John in Tinker, 1998; Barbuta in sod., 2015). Mauko Pranjič in sod. (2014) poročajo, da med najbolj perspektivne industrijske odpadke za uporabo $\mathrm{v}$ gradbeništvu spadajo žlindra ter elektrofiltrski pepel iz sežiga premoga, biomase, komunalnih odpadkov in papirniškega mulja. Poleg tega je v primerih, kadar odpadki niso okolijsko inertni, možno nevarne komponente trajno imobilizirati $\mathrm{z}$ različnimi vezivi ali postopki (Colliviginarelli in Sorlini, 2002; Mauko Pranjič in sod., 2014; Ramesh in sod., 2014; Chuang in sod., 2018). Imobilizacija potencialno nevarnih snovi (PNS) v odpadkih poteka s pravim razmerjem materialov, ustrezno vlago in zgoščevanjem med vgradnjo in tako PNS ne ogrožajo okolja (Pavlin in sod., 2018). Kljub temu pa obstaja dvom o učinkovitosti vgrajevanja odpadkov, ki temelji na interakciji med gradbenimi materiali in okoljem, $\mathrm{v}$ katerem so vgrajeni (Podlipnik, 2019). Ugotavljanje stanja v okolju, kjer so gradbeni kompoziti že vgrajeni, je torej ključno za boljše razumevanje te problematike in predstavlja pomemben izziv za strokovnjake iz področja varstva okolja.

Ta prispevek vključuje rezultate in ugotovitve prve raziskave (Cerar in Bavec, 2017) že vgrajenih gradbenih kompozitov, ki se uporabljajo kot sanacijski material na opuščenem kopu Drtija (Moravče). Glavni cilj tega pri- 
spevka je $\mathrm{z}$ uporabo geokemičnih preiskav opredeliti: (1) kemično sestavo sanacijskega materiala, okoliških površinskih tal in izcednih vod obravnavanega območja ter njihovo medsebojno povezavo ter (2) potencialni vpliv sanacijskega materiala na bodočo rekultivacijo. $\mathrm{Na}$ podlagi ugotovitev je predlagana tudi vrsta prostorske rabe po končni sanaciji.

\section{MATERIAL IN METODE}

\subsection{OBRAVNAVANO OBMOČJE}

Obravnavano območje se nahaja približno 1 $1,5 \mathrm{~km}$ vzhodno od Moravč, približno $30 \mathrm{~km}$ vzhodno od Ljubljane. Razprostira se med dolino potoka Drtijščice, na zahodu, naseljem Zgornja Dobrava na vzhodu, naseljem Straža pri Moravčah na severu ter z obrati in poslovno stavbo Termit na jugu (Slika 1).

Obravnavano območje predstavlja umetni zasip nekdanjega odkopa kremenovega peska Drtija s sanacijskim materialom. $\mathrm{V}$ okolici se nahajajo večinoma gozdne in kmetijske površine. Vzhodno od obravnavanega območja se nahaja usedalni bazen (Slika 1), ki je urejen $\mathrm{z}$ varnostnim nasipom za preprečevanje izliva vode $\mathrm{v}$ okolje. Usedalni bazen je nastal kot posledica pridobivanja kremenovega peska, zaradi česar je nastala depresija, v kateri so se zadrževale oziroma izlivale meteorne vode z območja peskokopa ter iz potoka Stražca.

$\mathrm{V}$ morfološkem pogledu gre za podolgovato območje površine približno 5 ha, ki se razprostira $\mathrm{v}$ smeri vzhod - zahod. Nadmorska višina območja je približno $380 \mathrm{~m}$.

Najpomembnejši vodotok predstavlja potok Drtij- ščica, ki teče približno $400 \mathrm{~m}$ južno od obravnavanega območja. Drtijščica izvira na treh lokacijah pod Sv. Lenartom na nadmorski višini približno $550 \mathrm{~m}$. Njena struga poteka v smeri vzhod - zahod, pri vasi Drtija pa povije proti severu. Ob naselju Trnava se izliva v reko Radomljo na približno 340 m n. v. (Atlas okolja, 2019).

Pomemben vodotok predstavlja tudi potok Stražca, ki teče na severnem obrobju obravnavanega območja $\mathrm{v}$ smeri proti zahodu, kjer se pri naselju Zalog pri Moravčah izliva v Drtijščico. Potok Stražca izvira na treh lokacijah na severovzhodni strani območja, na nadmorski višini približno $420 \mathrm{~m}$.

Geološke razmere na obravnavanem območju opredeljuje sinklinalna struktura, zapolnjena s plastmi neogenskih sedimentov (lapornata glina (sivica), kremenovi peski, prod in peščena glina), imenovana Moravška sinklinala. Podlago neogenskim sedimentom predstavljajo $\mathrm{v}$ glavnem zgornjetriasni plastoviti in masivni apnenci ter dolomiti, ki izdanjajo v severnem in južnem krilu sinklinale, mestoma pa še karnijski laporovec in laporast apnenec. Iz teh kamnin je zgrajeno tudi južno in severno obrobje Moravške doline. Južno sinklinalno krilo ima strmejši vpad kot severno sinklinalno krilo. Skupna debelina terciarnih plasti v Moravški sinklinali znaša okrog $250 \mathrm{~m}$, medtem ko je na obravnavanem območju debelina ocenjena na približno 90 m (Lapajne, 1993).

Terciarni sedimenti so pričakovano srednje prepustni $\left(\mathrm{K} \sim 4,6 \times 10^{-6} \mathrm{~m} \mathrm{~s}^{-1}\right)$, prav tako je izdatnost vodnjakov $\mathrm{v}$ teh sedimentih ocenjena na 3-4 $1 \mathrm{~min}^{-1}$ (Marinko in sod., 1975). Prepustnost apnencev je ocenjena na $3,88 \times 10^{-3} \mathrm{~m} \mathrm{~s}^{-1}$ (Rogelj in Karahodžič, 2004). Gladina podzemne vode se lokalno lahko nahaja na kontaktu med krovnino in talnino različnih slojev terciarnih se-

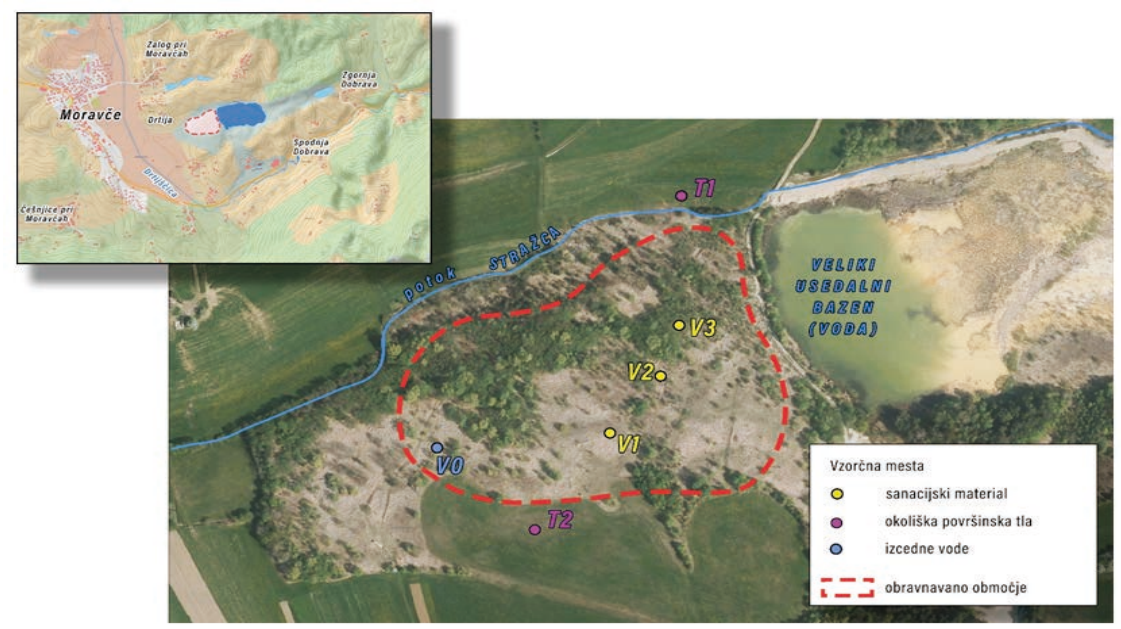

Slika 1: Obravnavano območje z lokacijami vzorčenja na letalskem posnetku med leti 2009 in 2011

Figure 1: Study area with sampling locations on an aerial photo map between 2009 and 2011 


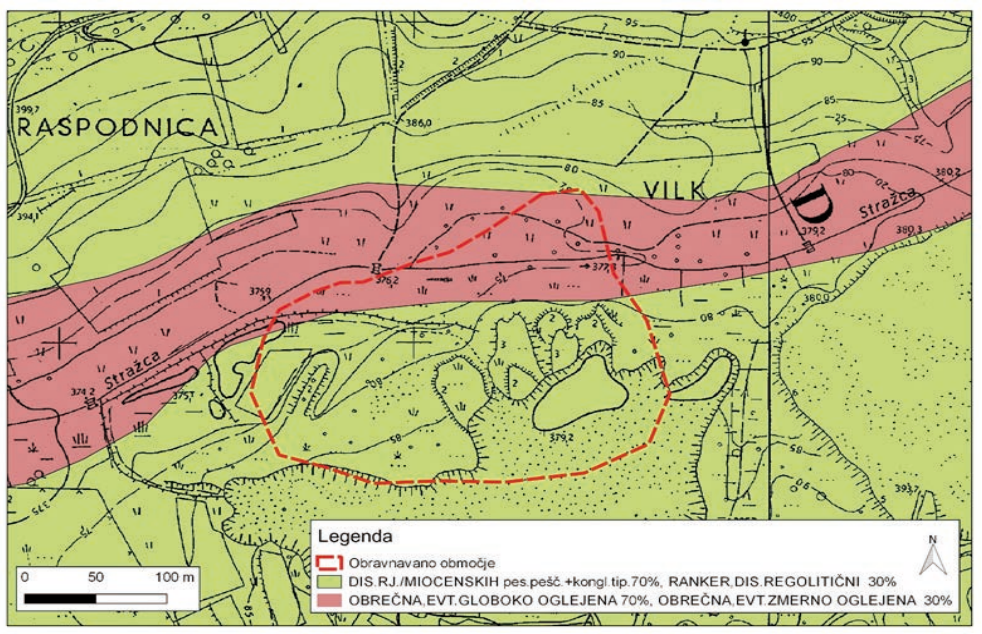

Slika 2: Pedološka karta obravnavanega območja v merilu 1:25000 (Vir: MKGP, 2016)

Figure 2: Pedological map of study area at scale 1:25.000 (Source: MAFF, 2016)

dimentov (kremenov pesek, glina, lapor, itd.). Smer toka podzemne vode je od vzhoda proti zahodu (Lapajne, 1993).

Glede na Pedološko karto Slovenije 1:25.000 (MKGP, 2016) se na miocenskih peskih, peščenjakih in konglomeratih nahajajo distrična rjava tla $(70 \%)$ in distrični regolitični ranker (30\%), na aluviju pa obrečna, evtrična globoko oglejena tla (70 \%) in obrečna, evtrična zmerno oglejena tla (30 \%) (Slika 2).

Večji del obravnavanega območja predstavlja rudarski prostor $\mathrm{z}$ odkopi kremenovega peska in saniranimi območji. Posledično so bila v večji meri avtohtona tla odstranjena. Le ta pa se predvidoma nahajajo izven rudarskega prostora.

\subsection{IZVEDBA TEHNIČNE SANACIJE IN REKUL- TIVACIJE TAL}

Po podatkih podjetja Termit d. d. je ob svojem nastanku, leta 1960, podjetje pričelo izkoriščati pesek v zahodnem delu, ki predstavlja obravnavano območje. $\mathrm{Na}$ tem območju se je izkoriščanje zaključilo leta 1978. Odkopani del se je najprej uporabljal kot bazen za vodo iz separacije. Bazen se je polnil $\mathrm{z}$ vodo približno šest let (Slika 3a). Nato so s krovninskimi materiali in glinami zapolnili odkop (Slika 3b). Med tem časom se je teren počasi sušil in utrjeval, dokler ni postal toliko trden, da so ga lahko spomladi leta 1993 poravnali z buldožerjem. Poravnan teren so nato še zasejali s travo (Slika 3c). Na površino 7 ha so navozili rodovitni material, ga pognojili in zatravili (Slike 3d, e in f). To območje takrat še ni bilo dokončno sanirano, saj je bilo zaraščeno $\mathrm{z}$ močvirskim drevjem in močvirsko travo in kot ta- kšno neuporabno za kmetijsko obdelavo. Zato so leta 2015 na obravnavanem območju v skladu z rudarskim projektom (Vajović in sod., 2016) pričeli z izvajanjem končne tehnične sanacije opuščene odkopne jame peskokopa. Kot sanacijski material se od takrat uporabljajo različni gradbeni kompoziti (Pavlin in sod., 2018). Gradbene kompozite proizvaja Termit, in sicer s predelavo nenevarnih odpadkov in dodajanjem naravnega materiala, t. j. kremenovega peska. Delež in sestava sta skladna s predhodno pridobljenim Slovenskim tehničnim soglasjem (STS), ki ga na podlagi Zakona o gradbenih proizvodih (ZGPro) podeljuje Zavod za gradbeništvo Slovenije (ZAG).

Tehnična sanacija $\mathrm{v}$ času preiskav še ni bila dokončno izvedena. Glede na rudarski načrt (Vajović in sod., 2016) je predvideno, da bo po končani tehnični sanaciji terena, ki predstavlja zasutje odkopanega prostora in izravnavo brežin do končnega naklona, izvedena rekultivacija vrhnjega sloja površin (Slika 4). Pri tem je navedeno, da se lahko $\mathrm{v}$ primeru resnih interesov in ustrezne podpore s strani občine ali lokalnih skupnosti, območje uredi tudi v druge namene (npr. turizem, rekreacija, raziskovalno območje ali kakršnokoli druga raba).

\subsection{VZORČENJE}

\subsubsection{Sanacijski material}

Vzorčenje sanacijskega materiala je bilo izvedeno z bagrskimi izkopi dne 15.3.2017 do globine $3 \mathrm{~m}$ na 3 vzorčnih mestih V1, V2 in V3 (Preglednica 1, Slika 1). Odvzeli smo dva tipa vzorcev: porušene in neporušene 

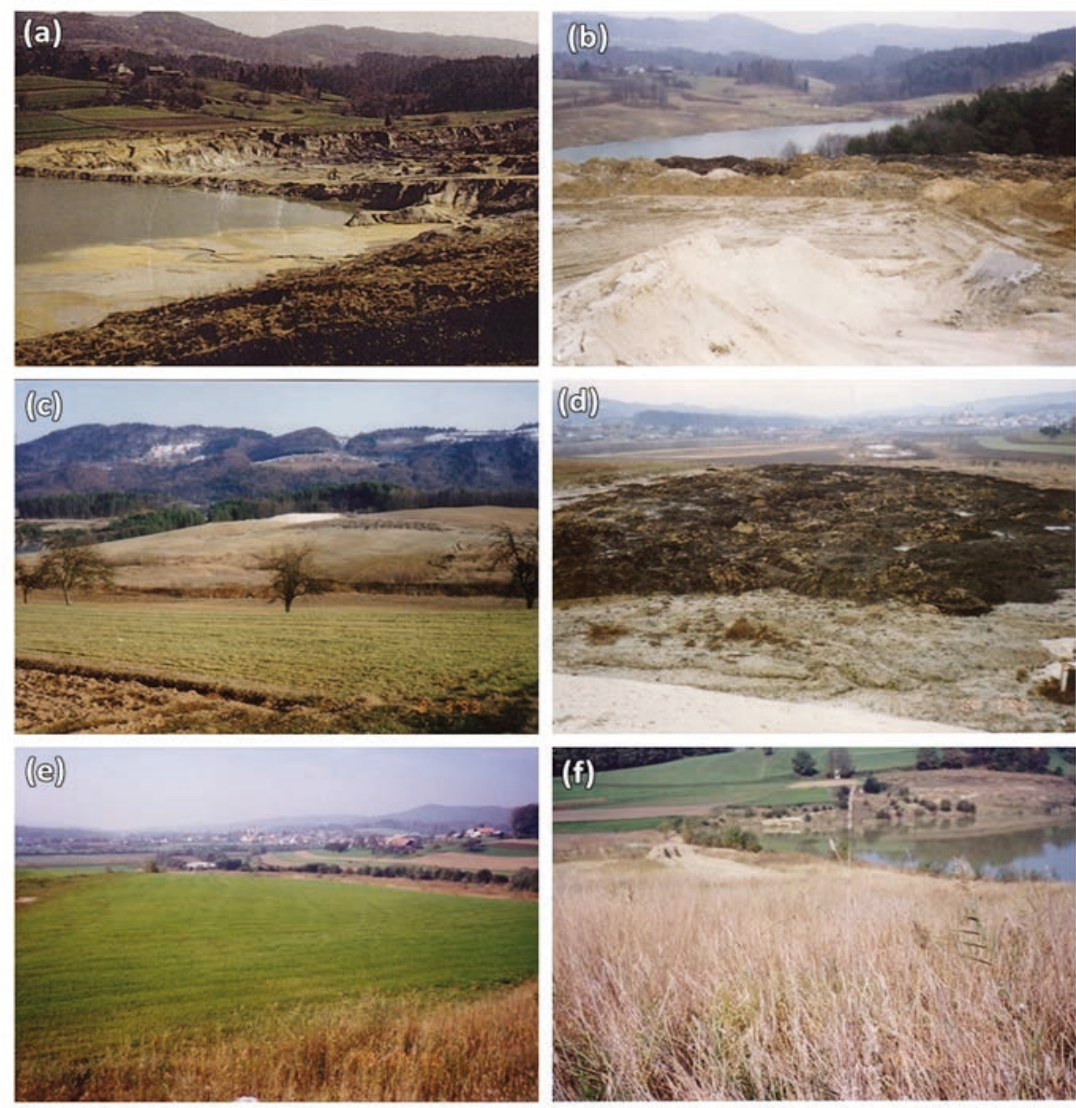

Slika 3: Prikazi stanja okolja na območju peskokopa Drtija od leta 1981 do 1996: (a) leto 1981- zasipavanje s separacijskim muljem, (b) leto 1992 - teren zapolnjen s krovnino in glino, (c) leto 1993 - poravnan teren (približno 7 ha), (d) leto 1993 - nasutje rodovitnega materiala (mulj iz bližnjega ribnika), (e) letnica neznana - stanje po sanaciji in rekultivaciji, (f) 1995 - stanje po sanaciji in rekultivaciji (vir fotografij: Termit d. d.)

Figure 3: Indications of the environment in the area of the Drtija sand pit from 1981 to 1996: (a) year 1981 - backfill with separation sludge, (b) year 1992 - terrain filled with roof and clay, (c) year 1993 - leveled terrain (ca. 7 ha), (d) 1993 - Spillage of fertile material (sludge from a nearby pond), (e) Year unknown - Condition after rehabilitation and recultivation, (f) 1995 - Condition after rehabilitation and recultivation (Photo source: Termit d. d.)

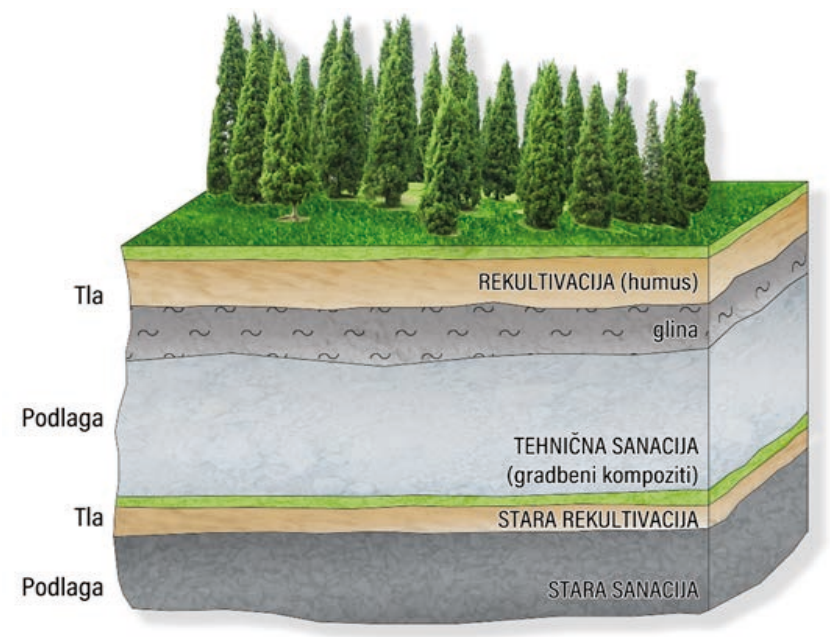

Slika 4: Shema tehnične sanacije in rekultivacije vrhnjega sloja (prirejeno po Vajović in sod., 2016).

Figure 4: Scheme of technical rehabilitation and recultivation of the upper layer (adapted after Vajović et al., 2016) 
vzorce. Slednji opredeljujejo dejansko stanje v naravi. Porušene vzorce sanacijskega materiala smo odvzeli iz izraženih plasti, ki so se pojavljale na različnih globinah. Odvzeli smo približno $3 \mathrm{~kg}$ vzorca. Približno $2 \mathrm{~kg}$ porušenega vzorca smo na terenu spravili $v$ plastične vrečke za anorganske analize in v stekleno embalažo za organske analize ter $1 \mathrm{~kg}$ vzorca za arhiv v steklene embalaže. Za vsak vzorec smo na terenu zabeležili tudi njegove lastnosti (tekstura, vlažnost, barva in podobno).

Neporušene vzorce, ki v primerjavi s porušenimi vzorci predstavljajo dejanske razmere na terenu, smo na vzorčnih mestih V1, V2 in V3 odvzeli s cilindrom velikosti $14 \mathrm{~cm}$ x $35 \mathrm{~cm}$. Globine, na katerih smo vtisnili cilinder, so podane v Preglednici 1.

\subsubsection{Okoliška površinska tla}

Ker smo tekom vzorčenja sanacijskega materiala opazili, da pri vgrajevanju sanacijskih materialov prihaja do prašenja delcev v bližnjo okolico, smo odvzeli tudi vzorce okoliških površinskih travniških tal z namenom ugotavljanja vpliva dejavnosti vgrajevanja sanacijskih materialov preko emisij iz zraka. Lokacije odvzema so bile pogojene $\mathrm{z}$ rabo tal. Travniška tla, za katera smo predvideli, da že dlje časa niso bila orana, so bila na voljo v ozkem pasu severno in jugovzhodno od obravnavanega območja. Drugod so bile obdelovalne kmetijske površine, gosto grmičevje ali gozd. Tako smo na dveh vzorčnih mestih (T1 in T2) (Preglednica 2) določili nulto stanje tal, kjer je možno dolgoročno spremljanje

Preglednica 1: Pregled podatkov o vzorčnih mestih sanacijskih materialov in njihovih lastnosti

Table 1: Review of data on sample sites of rehabilitation materials and their properties

\begin{tabular}{|c|c|c|c|c|c|c|}
\hline $\begin{array}{l}\text { Oznaka vzorč- } \\
\text { nega mesta }\end{array}$ & GKX & GKY & $\begin{array}{l}\text { Oznaka } \\
\text { vzorca }\end{array}$ & Globina $(\mathrm{m})$ & Lastnosti materialov & Metoda vzorčenja \\
\hline \multirow[t]{6}{*}{ V1 } & 109953 & 481789 & $\mathrm{~V} 1 \mathrm{G} 1$ & $0-0,95$ & $\begin{array}{l}\text { Material je temno sive barve, peščene teksture, } \\
\text { suh, smrdi po prežganem }\end{array}$ & $\begin{array}{l}\text { Bagrski izkop, vzor- } \\
\text { čenje iz žlice }\end{array}$ \\
\hline & & & V1G2 & $0,95-1,35$ & Material je svetlo sive barve, peščene teksture, suh & \\
\hline & & & V1G3 & $1,35-1,55$ & $\begin{array}{l}\text { Material je črne barve, glinaste teksture } \mathrm{z} \text { vidnimi } \\
\text { primesmi peska, suh, gnetljiv }\end{array}$ & \\
\hline & & & V1G4 & $1,55-1,75$ & $\begin{array}{l}\text { Material je rumenorjave barve, glinaste teksture z } \\
\text { vidnimi primesmi peska, suh/svež, enak material } \\
\text { se ponovno pojavi na globini med 2,2- } 2,6 \mathrm{~m}\end{array}$ & \\
\hline & & & V1G5 & $1,75-2,20$ & $\begin{array}{l}\text { Material je temno rjave barve, glinaste teksture z } \\
\text { vidnimi primesmi peska, moker }\end{array}$ & \\
\hline & & & $\mathrm{V} 1$ & $0,95-1,30$ & Material je enak V1G2 & $\begin{array}{l}\text { Bagrski izkop, vtis } \\
\text { cilindra ( } 14 \mathrm{~cm} \text { x } 35 \\
\mathrm{~cm}) \mathrm{z} \text { bagrsko žlico }\end{array}$ \\
\hline \multirow[t]{4}{*}{$\mathrm{V} 2$} & 109999 & 481826 & V2G1 & $0-0,80$ & $\begin{array}{l}\text { Material je temno sive barve, peščene teksture, } \\
\text { suh, mestoma se pojavljajo leče materiala svetlo } \\
\text { sive barve }\end{array}$ & $\begin{array}{l}\text { Bagrski izkop, vzor- } \\
\text { čenje iz žlice }\end{array}$ \\
\hline & & & V2G2 & $0,85-1,85$ & Material je enak V2G1 & \\
\hline & & & V2G3 & $1,85-2,40$ & $\begin{array}{l}\text { Material je sive barve, glinaste teksture, vlažen, } \\
\text { gnetljiv, mestoma se pojavljajo leče materiala } \\
\text { enakega kot pri V1G4 }\end{array}$ & \\
\hline & & & $\mathrm{V} 2$ & $1-1,35$ & Material je enak V2G1 & $\begin{array}{l}\text { Bagrski izkop, vtis } \\
\text { cilindra ( } 14 \mathrm{~cm} \text { x } 35 \\
\mathrm{~cm}) \mathrm{z} \text { bagrsko žlico }\end{array}$ \\
\hline \multirow[t]{4}{*}{$\mathrm{V} 3$} & 110042 & 481841 & V3G1 & $0-0,85$ & Material je enak V2G3 & $\begin{array}{l}\text { Bagrski izkop, vzor- } \\
\text { čenje iz žlice }\end{array}$ \\
\hline & & & V3G2 & $0,85-2,15$ & Material je enak V1G3 & \\
\hline & & & V3G3 & $2,15-2,85$ & $\begin{array}{l}\text { Material je kremenov pesek, neprijetnih vonjav, } \\
\text { suh/svež }\end{array}$ & \\
\hline & & & V3 & $1,00-1,35$ & Material je enak V3G2 & $\begin{array}{l}\text { Bagrski izkop, vtis } \\
\text { cilindra (14 cm x } 35 \\
\mathrm{~cm}) \mathrm{z} \text { bagrsko žlico }\end{array}$ \\
\hline
\end{tabular}


Preglednica 2: Pregled podatkov o vzorčnih mestih tal in lastnosti tal Table 2: Review of soil sample site data and soil properties

\begin{tabular}{|c|c|c|c|c|c|c|}
\hline $\begin{array}{l}\text { Oznaka vzorčnega } \\
\text { mesta }\end{array}$ & GKX & GKY & $\begin{array}{l}\text { Metoda } \\
\text { vzorčenja }\end{array}$ & $\begin{array}{l}\text { Oznaka } \\
\text { vzorca }\end{array}$ & $\begin{array}{l}\text { Globina } \\
(\mathrm{cm})\end{array}$ & Lastnosti tal \\
\hline $\mathrm{T} 1$ & 110147 & 481844 & $\begin{array}{l}\text { Kompozitno } \\
\text { vzorčenje }\end{array}$ & $\mathrm{T} 1$ & $0-10$ & $\begin{array}{l}\text { Tla so bila ob vzorčenju sveža/vlažna, humo- } \\
\text { zna, gosto prekoreninjena, drobljiva z dobro } \\
\text { izraženo mrvičasto do grudičasto strukturo, te- } \\
\text { renska ocena teksturo je peščena ilovica, barva } \\
10 Y R \quad 4 / 4 \text { (Munsell Soil), vsebnost skeleta oce- } \\
\text { njena na } 5 \% \mathrm{~s} \text { prevladujočo velikostjo ostroro- } \\
\text { bih delcev } 0,5 \mathrm{~cm} \text {. }\end{array}$ \\
\hline
\end{tabular}

\begin{tabular}{llllll}
\hline T2 109873 & 481733 & $\begin{array}{l}\text { Kompozitno } \\
\text { vzorčenje }\end{array}$ & T2 & $0-10$
\end{tabular}

Tla so bila ob vzorčenju vlažna, srednje hu-
mozna, gosto prekoreninjena, zbita, mazava in
gnetljiva z dobro izraženo mrvičasto do grudi-
často strukture, terenska ocena teksture je pe-
ščena glinasta ilovica, barva $10 Y \mathrm{Y}$ $3 / 3$ (Munsell
Soil), vsebnost skeleta ocenjena na $30 \% \mathrm{~s}$ pre-
vladujočo velikostjo peščenih delcev (kreme-
nov pesek), pojavljajo se tudi zaobljeni delci z
velikostjo do $2 \mathrm{~cm}$. kvalitete tal v bližnji okolici, glede na to, da se sanacijski materiali trenutno še vgrajujejo. Poleg tega smo lahko primerjali vrednosti kemijskih snovi $\mathrm{v}$ tleh in sanacijskih materialih ter ugotavljali njuno povezavo. Vzorčenje tal je bilo izvedeno dne 21.4.2017. Izbrali smo sistem kompozitnega vzorčenja tako, da je vsak odvzeti vzorec sestavljen iz petih podvzorcev, ki smo jih homogenizirali na terenu. Prvi podvzorec je bil odvzet na GK koordinatah obravnavanega vzorčnega mesta, preostali podvzorci so bili odvzeti na krožnici, s centrom na koordinati prvega podvzorca in polmerom $5 \mathrm{~m}$; drugi podvzorec $\mathrm{v}$ smeri $\mathrm{V}$, tretji podvzorec $\mathrm{v}$ smeri $\mathrm{S}$, četrti podvzorec $\mathrm{v}$ smeri $\mathrm{Z}$ in peti podvzorec $\mathrm{v}$ smeri J. Odvzeli smo po en združen vzorec na vsakem vzorčnem mestu, na globini $0-10 \mathrm{~cm}$. Skupna teža posameznega vzorca je znašala približno $3 \mathrm{~kg}$. Homogenizirani vzorec smo razdelili na posamezne dele za nadaljnje analize in jih spravili v stekleno embalažo (približno $2 \mathrm{~kg}$ za določitev anorganskih in organskih parametrov ter približno $1 \mathrm{~kg}$ za arhiv).

\subsubsection{Izcedne vode}

Da bi preverili možnost prehajanja kemijskih snovi iz sanacijskega materiala $\mathrm{v}$ okolje preko vode, smo poleg uporabe izluževalnih testov odvzeli tudi vzorec izcedne vode (VO). Izcedna voda na obravnavanem območju predstavlja infiltrirano padavinsko vodo, ki se preceja skozi sanacijski material. Glede na to, da je obravnavano območje zgrajeno v obliki nasipa, je bilo možno izcedno vodo odvzeti le na dnu brežine tega nasipa, saj odvodnja izcedne vode na dan vzorčenja ni bila urejena. Tako je bil vzorec izcedne vode odvzet dne 20.4.2017 na zahodnem delu obravnavanega območja z GKX 109941 in GKY 481661 (Slika 1), kjer je bil odvzem vzorca možen (na območju preostalih brežin izcedna voda ni bila prisotna).

Pred vzorčenjem vode smo izvedli tudi meritve terenskih parametrov (temperatura vode, $\mathrm{pH}$ in električna prevodnost vode) $\mathrm{z}$ uporabo instrumenta WTW $\mathrm{pH} /$ Cond 340i $\mathrm{SET}^{\mathrm{TM}}$ in meritve oksidacijsko-redukcijskega potenciala ter nasičenosti s kisikom v vodi, z instrumentom WTW Multi 3410/set C. Ob vzorčenju je bil ocenjen tudi pretok vode. Vzorci vode za organske parametre so bili odvzeti v rjavih steklenih embalažah oziroma steklenih vialah, medtem ko so bili za osnovne kemijske parametre ter kovine vzorci odvzeti v plastičnih embalažah različne kapacitete. Vsi vzorci izcedne vode so bili na terenu ustrezno obdelani s filtriranjem oziroma stabiliziranjem $\mathrm{z}$ dodajanjem različnih kislin.

\subsection{KEMIJSKE ANALIZE}

Predpriprava porušenih vzorcev sanacijskih materialov, vodnih izlužkov porušenih vzorcev sanacijskih materialov po standardu 2003/33/EC, tal in vod za fizikalno-kemijske in kemijske analize $\mathrm{z}$ uveljavljenimi standardnimi metodami, je bila opravljena $\mathrm{v}$ zunanjem akreditiranem (CSN EN ISO/IEC 17025:2005) laboratoriju ALS Czech Republic, s. r. o. Predpriprava neporušenih vzorcev sanacijskih materialov za fizikalno-kemijske analize je bila opravljena na Zavodu 
za gradbeništvo (ZAG). Pripravili so vodne izlužke po standardu SIST EN 1744-1:2010+A1:2013, katerih meritev analiznih parametrov so prav tako opravili $\mathrm{v}$ zunanjem akreditiranem laboratoriju ALS Czech Republic, s. r. o.. Izmerjene vrednosti parametrov podane $\mathrm{v}$ $\mathrm{mg} / \mathrm{l}$, so bile za interpretacijo preračunane $\mathrm{v} \mathrm{mg} \mathrm{kg}{ }^{-1} \mathrm{~s}$. s. $v$ skladu $z$ razmerjem med maso vzorca in izluževalnega sredstva (destilirana voda) 1:10, računano na suho snov vzorca, zato da smo jih lahko ovrednotili v skladu s predpisanimi vrednostmi ( $\mathrm{mg} \mathrm{kg}^{-1}$ s. s.) za inertne odpadke.

Da bi preverili možnost prehajanja kemijskih snovi $\mathrm{v}$ okolje smo $\mathrm{v}$ porušenih in neporušenih vzorcih sanacijskega materiala določili parametre vodnega izlužka inertnih odpadkov (kovine, kloridi, fluoridi, sulfati, fenolni indeks, raztopljeni organski ogljik (DOC) in celotne raztopljene snovi), medtem ko smo v vodnih izlužkih neporušenih vzorcev dodatno določili kalcij, magnezij, natrij in kalij. Za karakterizacijo kemične sestave materialov smo $\mathrm{v}$ porušenih vzorcih sanacijskih materialov in tal določili celotne vsebnosti kovinskih anorganskih snovi in organskih snovi (celotni organski ogljik (TOC), ogljikovodiki (C10-C40), lahkohlapni aromatski ogljikovodiki (BTEX), policiklični aromatski ogljikovodiki (PAH), poliklorirani bifenili (PCB), formaldehid, fenol, naftol in krezol. $\mathrm{V}$ porušenih vzorcih tal smo določili še vsebnosti nekovinskih anorganskih parametrov (bromid, klorid, fluorid, nitrat, sulfat). Pri tem je potrebno omeniti, da smo analizirali 7 (od skupno 11) vzorcev porušenih sanacijskih materialov (V1G1, V1G5, V2G1, V2G2, V2G3, V3G2, V3G3), ki so glede na terensko oceno teksture bolje prepustni ( $v$ materialu prevladujejo peščeni delci).

$\mathrm{V}$ vzorcu izcedne vode smo analizirali iste parametre kot so bili analizirani v sanacijskem materialu in vodnih izlužkih, in sicer: osnovne kemijske parametre, raztopljene kovine ter nekatere organske parametre (adsorbljivi organski halogeni (AOX), fenolni indeks in fenolni derivati, celotni organski ogljik (TOC), celotni ogljikovodiki - mineralna olja (C10-C40), lahkohlapni aromatski ogljikovodiki (BTEX), policiklični aromatski ogljikovodiki (PAH) in formaldehid).

Merilna negotovost analitske metode je podana $\mathrm{v}$ poglavju 3. skupaj z rezultati kemijskih analiz vseh preiskovanih medijev.

\subsection{VREDNOTENJE REZULTATOV}

Za vrednotenje rezultatov kemijskih analiz sanacijskih materialov smo uporabili veljavne predpise. Za vrednotenje rezultatov vodnih izlužkov smo uporabili mejne vrednosti vodnega izlužka inertnih odpadkov, ki so predpisane v Uredbi o odlagališčih odpadkov (2014). Za vrednotenje rezultatov kovinskih anorganskih snovi smo uporabili največje dovoljene vrednosti anorganskih parametrov $\mathrm{v}$ umetno pripravljeni zemljini, ki je namenjena nasipavanju stavbnih zemljišč in nasipavanju območij mineralnih surovin za zapolnitev tal po izkopu, ki so predpisane v Uredbi o obremenjevanju tal Z vnašanjem odpadkov (2008 in 2011). Za vrednotenje organskih snovi smo uporabili mejne vrednosti parametrov onesnaženosti inertnih odpadkov, ki so predpisane v Uredbi o odlagališčih odpadkov (2014).

Izmerjene vrednosti analiznih parametrov $\mathrm{v}$ tleh smo primerjali z mejnimi, opozorilnimi in kritičnimi vrednostmi, ki jih predpisuje Uredba o mejnih, opozorilnih in kritičnih imisijskih vrednostih nevarnih snovi $\mathrm{v}$ tleh (1996) ter povprečnimi vrednostmi elementov v slovenskih tleh (Gosar in sod., 2019). Izračunali smo faktorje obogatitve za posamezen element v odvzetih vzorcih tal tako, da smo izmerjene vrednosti delili s povprečnimi vrednostmi elementov v slovenskih tleh (Gosar in sod., 2019).

Za vrednotenje izcedne vode na obravnavanem območju so pomemben kriterij mejne vrednosti določene $z$ Uredbo o emisiji snovi pri odvajanju izcedne vode iz odlagališč odpadkov (2008). Ker z omenjeno uredbo niso določene mejne vrednosti za nekatere anorganske in organske snovi smo za oceno vrednotenja uporabili še mejne vrednosti določene $z$ Uredbo o emisiji snovi in toplote pri odvajanju odpadnih voda $\mathrm{v}$ vode in javno kanalizacijo (2012) ter kot najstrožji kriterij vrednotenja vod, Pravilnik o pitni vodi (2004). Uporaba teh mejnih vrednosti predstavlja konzervativen pristop vrednotenja rezultatov kemijskih analiz izcedne vode saj oba predpisa obravnavata drug tip voda in jih tako lahko uporabimo le kot primerjavo.

\section{REZULTATI IN DISKUSIJA}

\subsection{SANACIJSKI MATERIAL}

\subsubsection{Celotne vsebnosti anorganskih snovi}

Kemične analize so pokazale, da so celotne vsebnosti antimona in selena pod spodnjo mejo določanja (LOQ) v vseh obravnavanih vzorcih. Pri ostalih kovinah smo za izračun osnovnih statistik za vrednosti manjše od LOQ upoštevali polovične vrednosti LOQ. Preiskovani materiali vsebujejo arzen (As), kadmij (Cd), krom $(\mathrm{Cr})$, baker $(\mathrm{Cu})$, živo srebro $(\mathrm{Hg})$, nikelj $(\mathrm{Ni})$ in cink (Zn) (Preglednica 3), katerih vsebnosti smo za splošno oceno kakovosti materialov, ovrednotili glede na smernice anorganskih parametrov (As, $\mathrm{Cd}, \mathrm{Cr}, \mathrm{Cu}, \mathrm{Hg}, \mathrm{Ni}, \mathrm{Pn}$ 
Preglednica 3: Celokupne vrednosti kovin in $\mathrm{As}\left(\mathrm{mg} \mathrm{kg}^{-1} \mathrm{~s}\right.$ s.) v porušenih vzorcih sanacijskega materiala skupaj z mejnimi vrednostmi parametra za umetno pripravljeno zemljino (MV) ter osnovnimi statistikami

Table 3: The total values of metals and As $\left(\mathrm{mg} \mathrm{kg}^{-1} \mathrm{~d} . \mathrm{m}\right)$ in demolished samples of rehabilitation material, together with the limit values of the parameter for artificially prepared soil (MV) and basic statistics

\begin{tabular}{lllllllllll}
\hline Oznaka vzorca & $\mathrm{As}$ & $\mathrm{Ba}$ & $\mathrm{Cd}$ & $\mathrm{Cr}$ & $\mathrm{Cu}$ & $\mathrm{Hg}$ & $\mathrm{Mo}$ & $\mathrm{Ni}$ & $\mathrm{Pb}$ & $\mathrm{Zn}$ \\
\hline V1G1 & 5,0 & 128 & 0,2 & 17,9 & 17,5 & 0,099 & 0,60 & 14,7 & 51,1 & 50,2 \\
V1G5 & 4,44 & 86,7 & 0,2 & 16,5 & 13,2 & 0,073 & 0,98 & 14 & 41,4 & 41,3 \\
V2G1 & $<2,5$ & 286 & 2,82 & 2.260 & 176 & 0,046 & 122 & 813 & 149 & 1.060 \\
V2G2 & $<2,5$ & 285 & 2,82 & 1.740 & 220 & 0,044 & 111 & 659 & 153 & 1.080 \\
V2G3 & $<2,5$ & 266 & 2,64 & 1.520 & 156 & 0,041 & 95 & 557 & 136 & 1.020 \\
V3G2 & $<2,5$ & 276 & $<0,4$ & 226 & 20 & $<0,01$ & 2,08 & 48,8 & 9,1 & 41,9 \\
V3G3 & 5,62 & 88,5 & 0,52 & 30,9 & 25,2 & 0,22 & 1 & 21 & 108 & 67,7 \\
$N^{1}$ & 7 & 7 & 7 & 7 & 7 & 7 & 7 & 7 & 7 & 7 \\
Min. & $<2,5$ & 86,7 & $<0,4$ & 16,5 & 13,2 & 0,041 & 0,6 & 14 & 9,1 & 41,3 \\
Max. & 5,0 & 286 & 2,82 & 2.260 & 220 & 0,22 & 122 & 813 & 153 & 1.080 \\
Povprečje & 2,86 & 202 & 1,3 & 830 & 89,7 & 0,1 & 47,5 & 304 & 92,5 & 480,2 \\
Mediana $^{2,5,5}$ & 266 & 0,52 & 226 & 25,2 & 0,05 & 2,08 & 48,8 & 108 & 67,7 \\
MN $^{2}$ & $\pm 20 \%$ & $\pm 20 \%$ & $\pm 20 \%$ & $\pm 20 \%$ & $\pm 20 \%$ & $\pm 20 \%$ & $\pm 20 \%$ & $\pm 20 \%$ & $\pm 20 \%$ & $\pm 20 \%$ \\
MV $^{3}$ & 30 & $/$ & 1,1 & 90 & 90 & 0,7 & $/$ & 55 & 100 & 450 \\
$\mathrm{X}^{4}>$ MV & 0 & $/$ & 3 & 4 & 3 & 0 & $/$ & 3 & 4 & 3 \\
\hline
\end{tabular}

${ }^{1}$ Število analiziranih vzorcev; ${ }^{2}$ Merilna negotovost analitske metode; ${ }^{3}$ Mejna vrednost za anorganske parametre v umetno pripravljeni zemljini (Uredba o obremenjevanju tal z vnašanjem odpadkov (2008)); ${ }^{4}$ Število vzorcev nad mejno vrednostjo

in $\mathrm{Zn}$ ) v umetno pripravljeni zemljini, ki je med drugim namenjena nasipavanju območij mineralnih surovin za zapolnitev tal po izkopu (Uredba o obremenjevanju tal Z vnašanjem odpadkov (2008)). Mejne vrednosti Cd, $\mathrm{Cr}, \mathrm{Cu}, \mathrm{Ni}, \mathrm{Pb}$ in $\mathrm{Zn}$ so presežene v vseh treh vzorcih sanacijskega materiala vertikalnega profila V2, in sicer V2G1, V2G2 ter V2G3, kar kaže na to, da so povečane vsebnosti podobno prostorsko porazdeljene. Podobna prostorska porazdelitev omenjenih kovin nakazuje na podoben izvor, ki so lahko livarski peski (Bożym, 2017), pepel in žlindra (Basu in sod., 2009). V vzorcih sanacijskega materiala vertikalnega profila V3 pa sta presežena tudi krom (V3G2) in svinec (V3G3). Mejne vrednosti As in $\mathrm{Hg}$ niso presežene. Glede na izbrane smernice, vgrajen sanacijski material ni primeren za zapolnitev tal po izkopu mineralnih surovin, saj so presežene mejne vrednosti celotnih vsebnosti posameznih kovin. Vendar pa je potrebno opozoriti, da uradno te smernice za tovrsten material (t. j. gradbeni kompozit) na obravnavanem območju ne veljajo, zato je napačno trditi, da ti materiali niso ustrezni. V okoljevarstvenih dovoljenjih družbe Termit d .d. je namreč opredeljeno, da se gradbene materiale lahko uporablja, če so izdelani v skladu s pridobljenim STS in če kemične lastnosti predelanih materialov ustrezajo zahtevam za inertne odpadke (Uredba o odlagališčih odpadkov (2014)).
Slednje pa ne predpisujejo mejnih vrednosti za celotne vsebnosti parametrov, temveč za parametre vodnega izlužka (1:10). To je na splošno gledano smiselno, saj celotne vsebnosti kovin še ne povedo veliko o njihovi mobilnosti oz. možnosti prehajanja v okolje - vodo in bioto, temveč so za to potrebne podrobnejše raziskave, in sicer fizikalno-kemijskih lastnosti, speciacije, vodotopnosti, biodostopnosti, itd. (De Matos in sod., 2001; Ogundiran in Osibanjo, 2009; Bavec in Gosar, 2016). $\mathrm{V}$ tej študiji smo ugotavljali vodotopnost, oz. možnost prehajanja kemičnih snovi iz sanacijskega materiala $\mathrm{v}$ vodo, kar so pokazale vrednosti, ki so bile izmerjene v vodnih izlužkih in izcedni vodi, ki so predstavljene v nadaljevanju.

Povprečna vsebnost barija je $202 \mathrm{mg} \mathrm{kg}^{-1}$ s. s. Značilne vsebnosti barija $\mathrm{v}$ naravnih - neobremenjenih, geoloških materialih so do $1.600 \mathrm{mg} / \mathrm{kg}$, v glinenih materialih do $3.000 \mathrm{mg} \mathrm{kg}^{-1}$ (Turekian in sod., 1961). Glede na sestavo materialov barij praviloma izvira iz karbonatnih materialov. Povprečna vsebnost molibdena je $47,5 \mathrm{mg} \mathrm{kg}^{-1}$ s. s.. Od povprečnih vrednosti odstopajo vzorci vertikalnega profila V2 in sicer vzorca V2G1 in V2G2 na globini do $2 \mathrm{~m}$, kjer izkopan material predstavlja temno siv pesek (material v večji meri povsem verjetno sestavlja livarski pesek) in vzorec V2G3, kjer izkopan material predstavlja sivo glino. Značilne vseb- 
Preglednica 4: Vrednosti organskih snovi ( $\mathrm{v} \mathrm{mg} \mathrm{kg} \mathrm{kg}^{-1}$ s. s., razen za TOC v \% s. s.), žarilne izgube (\% s. s.) in suhe snovi (\%) porušenih vzorcev sanacijskega materiala skupaj z mejnimi vrednostmi parametrov onesnaženosti za inertne odpadke ter osnovnimi statistikami

Table 4: Organic matter values (in $\mathrm{mg} \mathrm{kg}^{-1} \mathrm{~d}$. m., except for TOC in \% d. m.), incineration losses (\% d. m.) and dry matter (\%) of demolished rehabilitation material samples, together with limit values for contamination parameters for inert waste and basic statistics

\begin{tabular}{|c|c|c|c|c|c|c|c|}
\hline Parameter & TOC & $\mathrm{C} 10-\mathrm{C} 40$ & Vsota PAH & Vsota BTEX & Fenol & $\begin{array}{l}\text { Žarilna izguba } \\
550^{\circ} \mathrm{C}\end{array}$ & $\begin{array}{l}\text { Suha snov } \\
105^{\circ} \mathrm{C}\end{array}$ \\
\hline V1G1 & 3,23 & 137 & 0,50 & $<0,17$ & I & 7,3 & 76,9 \\
\hline V1G5 & 2,29 & $<20$ & $<0,16$ & $<0,17$ & / & 15,1 & 53,0 \\
\hline V2G1 & 1,75 & 22 & 0,64 & $<0,17$ & I & 10,6 & 67,1 \\
\hline V2G2 & 4,92 & 140 & 0,72 & 0,483 & 1,08 & 6,5 & 86,5 \\
\hline V2G3 & 0,45 & $<20$ & $<0,16$ & $<0,17$ & I & 5,5 & 77,2 \\
\hline V3G2 & 7,09 & 163 & 0,80 & 1,90 & I & 3,6 & 85,3 \\
\hline V3G3 & 1,42 & 42 & 0,31 & $<0,17$ & 0,30 & 0,9 & 94,9 \\
\hline $\mathrm{N}^{1}$ & 7 & 7 & 7 & 7 & 2 & 7 & 7 \\
\hline Min. & 0,45 & $<20$ & $<0,16$ & $<0,17$ & 0,30 & 0,9 & 53,0 \\
\hline Max. & 7,09 & 163 & 0,80 & 1,90 & 1,08 & 15,1 & 94,9 \\
\hline Povprečje & 3,02 & 75 & 0,45 & 0,40 & I & 7,0 & 77,3 \\
\hline Mediana & 2,29 & 42 & 0,50 & $<0,17$ & / & 6,5 & 77,2 \\
\hline $\mathrm{MN}^{2}$ & $\pm 20 \%$ & $\pm 30 \%$ & $\pm 30 \%$ & $\pm 40 \%$ & $\pm 40 \%$ & $\pm 5,0 \%$ & $\pm 6,0 \%$ \\
\hline $\mathrm{MV}^{3}$ & 3 & 500 & 6 & 6 & / & / & / \\
\hline $\mathrm{X}^{4}>\mathrm{MV}$ & 3 & 0 & 0 & 0 & 1 & 1 & / \\
\hline
\end{tabular}

${ }^{1}$ Število analiziranih vzorcev; ${ }^{2}$ Merilna negotovost analitske metode; ${ }^{3}$ Mejna vrednost parametrov onesnaženosti za inertne odpadke (Uredba o odlagališčih odpadkov (2014)); ${ }^{4}$ Število vzorcev nad mejno vrednostjo

nosti molibdena v naravnih - neobremenjenih, geoloških materialih so do $3 \mathrm{mg} \mathrm{kg}^{-1} \mathrm{oz}$. v glinenih materialih do $27 \mathrm{mg} \mathrm{kg}^{-1}$ (Turekian in sod., 1961).

\subsubsection{Celotne vsebnosti organskih snovi}

$\mathrm{V}$ preglednici 4 navajamo vsebnosti TOC-a, mineralnih olj, vsote BTEX, vsote PAH-ov in fenola skupaj $\mathrm{z}$ žarilno izgubo in suho snovjo. Vrednosti spojin iz sklopa PCB-jev - kongenerji 2,4,4 triklorobifenil (PCB 28), 2,2',5,5 tetraklorobifenil ( $\mathrm{PCB} 52$ ), 2,2',4,5,5' pentaklorobifenil (PCB 101), 2,3',4,4',5 pentaklorobifenil (PCB 118), 2,2',4,4,'5',5 heksaklorobifenil (PCB 153) in 2,2',3,4,4,5',5 heptaklorobifenil (PCB 180) ter formaldehidov, naftolov in krezolov so manjši od LOQ v vseh obravnavanih vzorcih, zato jih $\mathrm{v}$ preglednici 4 ne navajamo.

Preiskovani vzorci sanacijskega materiala vsebujejo v povprečju $80 \%$ suhe snovi (s. s.) oz. $20 \%$ vlage. Odstopa vzorec V1G5 s 53 \% s. s. oz. 47 \% vlage (Preglednica 4). Količina vlage je bila pričakovana, ker je bil vzorec v primerjavi z ostalimi vzorci, ki so bili pretežno suhi, že na terenu moker. Slednje pripisujemo teksturi vzorca (glina), ki predstavlja manj prepustno plast.

Ob upoštevanju vseh obravnavanih vzorcev je delež TOC-a skromen, v povprečju $3 \%$ s. s. Glede na povprečno vrednost žarilne izgube na $550{ }^{\circ} \mathrm{C}$, ki znaša $7 \%$ in izmerjene vsebnosti TOC (3,02 \% s. s.) je delež termično stabilnih materialov $\mathrm{v}$ preiskovanih zemljinah več kot $90 \%$. Glede na smernice za inertne odpadke (Uredba o odlagališčih odpadkov (2014)), je v manjši meri presežena mejna vrednost za TOC in sicer $\mathrm{v}$ treh vzorcih V1G1, V2G2 in V3G2. Glede na vrste odpadkov, iz katerih so gradbeni materiali sestavljeni, so vir povečanega TOC lahko odpadki iz predelave papirniškega mulja, predelave mulja iz vodnih vrtin, predelave vrtin in predelave fosfatov. Vsota PAH-ov, BTEX-ov ter vrednosti mineralnih olj ne presegajo mejnih vrednosti organskih parametrov za inertne odpadke. Glede na vrste odpadkov, iz katerih so sanacijski materiali sestavljeni, so vir BTEX lahko odpadki iz predelave livarskih peskov, predelave lepila in predelave mulja.

Fenol vsebujeta dva vzorca V2G2 in V3G3 sanacijskih materialov, ki sta pretežno sestavljena iz kremenovega oziroma livarskega peska. Odpadni materiali iz 
Preglednica 5: Vrednosti parametrov ( $\mathrm{mg} \mathrm{kg}^{-1}$ s. s.) v vodnih izlužkih porušenih vzorcev sanacijskega materiala skupaj z mejnimi vrednostmi parametrov izlužka za inertne odpadke ter osnovnimi statistikami

Table 5: Values of parameters $\left(\mathrm{mg} \mathrm{kg}^{-1} \mathrm{~d}\right.$. m.) in water leachates of demolished samples of rehabilitation material together with limit values of leachate parameters for inert waste and basic statistics

\begin{tabular}{|c|c|c|c|c|c|c|c|c|c|c|c|c|}
\hline \multicolumn{2}{|c|}{ Oznaka vzorca Ba } & \multirow{2}{*}{$\begin{array}{l}\mathrm{Cr} \\
<0,05\end{array}$} & \multirow{2}{*}{$\begin{array}{l}\mathrm{Cu} \\
<0,1\end{array}$} & \multirow{2}{*}{$\begin{array}{l}\mathrm{Hg} \\
<0,0001\end{array}$} & \multirow{2}{*}{$\begin{array}{l}\text { Mo } \\
<0,2\end{array}$} & \multirow{2}{*}{$\begin{array}{l}\mathrm{Zn} \\
0,18\end{array}$} & \multirow{2}{*}{$\begin{array}{l}\mathrm{Cl}^{-} \\
90\end{array}$} & \multirow{2}{*}{$\begin{array}{l}\mathrm{F}^{-} \\
5,86\end{array}$} & \multirow{2}{*}{$\begin{array}{l}\mathrm{SO}_{4}^{2-} \\
89\end{array}$} & \multirow{2}{*}{$\frac{\mathrm{DOC}}{67}$} & \multirow{2}{*}{$\frac{\mathrm{CRS}^{1}}{9.740}$} & \multirow{2}{*}{$\begin{array}{l}\text { Alkaliteta } \\
\text { pH 4,5 }\end{array}$} \\
\hline V1G1 & 18,70 & & & & & & & & & & & \\
\hline V1G5 & 5,18 & $<0,05$ & $<0,1$ & $<0,0001$ & $<0,2$ & $<0,1$ & 448 & 3,30 & 442 & 50 & 4.340 & 4,76 \\
\hline V2G1 & 2,75 & 0,20 & $<0,1$ & 0,00011 & $<0,2$ & $<0,1$ & 152 & 6,42 & 560 & 33 & 8.760 & 10,90 \\
\hline V2G2 & 1,50 & 4,46 & $<0,1$ & 0,00014 & 0,72 & 0,19 & 110 & 6,48 & 192 & 18 & 5.460 & 9,64 \\
\hline V2G3 & 0,57 & $<0,05$ & $<0,1$ & 0,0004 & $<0,2$ & $<0,1$ & 24 & 3,42 & 744 & $<5$ & 1.390 & 0,44 \\
\hline V3G2 & 0,21 & 0,87 & $<0,1$ & $<0,0001$ & 0,26 & $<0,1$ & 127 & 10,60 & 381 & 21 & 3.540 & 4,38 \\
\hline V3G3 & 2,63 & 0,07 & 0,48 & 0,00043 & $<0,2$ & 2,58 & 26 & 5,00 & 70 & 690 & 1.050 & 11,00 \\
\hline $\mathrm{N}^{2}$ & 7 & 7 & 7 & 7 & 7 & 7 & 7 & 7 & 7 & 7 & 7 & 7 \\
\hline Min. & 0,21 & $<0,05$ & $<0,1$ & $<0,0001$ & $<0,2$ & $<0,1$ & 24 & 3,30 & 70 & $<5$ & 1.050 & 0,44 \\
\hline Max. & 18,70 & 4,46 & 0,48 & 0,00043 & 0,72 & 2,58 & 448 & 10,60 & 744 & 690 & 9.740 & 17,90 \\
\hline Povprečje & 4,51 & 0,81 & 0,11 & 0,00 & 0,21 & 0,45 & 140 & 5,87 & 354 & 126 & 4.897 & 8,43 \\
\hline Mediana & 2,63 & 0,07 & $<0,1$ & 0,00011 & $<0,2$ & $<0,1$ & 110 & 5,86 & 381 & 33 & 4.340 & 9,64 \\
\hline $\mathrm{MN}^{3}$ & $\pm 10 \%$ & $\pm 10 \%$ & $\pm 10 \%$ & $\pm 10 \%$ & $\pm 10 \%$ & $\pm 10 \%$ & $\pm 10 \%$ & $\pm 10 \%$ & $\pm 10 \%$ & $\pm 10 \%$ & $\pm 10 \%$ & $\pm 10 \%$ \\
\hline $\mathrm{MV}^{4}$ & 20 & 0,5 & 2 & 0,01 & 0,5 & 4 & 800 & 10 & 1.000 & 500 & 4.000 & l \\
\hline $\mathrm{X}^{5}>\mathrm{MV}$ & 0 & 2 & 0 & 0 & 1 & 0 & 0 & 1 & 0 & 0 & 4 & I \\
\hline
\end{tabular}

${ }^{1}$ Celotne raztopljene snovi; ${ }^{2}$ Število analiziranih vzorcev; ${ }^{3}$ Merilna negotovost analitska metode; ${ }^{4}$ Mejna vrednost parametrov izlužka za inertne odpadke (Uredba o odlagališčih odpadkov (2014)); ${ }^{5}$ Število vzorcev nad mejno vrednostjo

predelave kremenovega peska in livarskega peska so lahko vir fenolov (Mcnaughtan in Hoyt, 1958).

\subsubsection{Vrednosti parametrov v vodnih izlužkih}

Vrednosti antimona, arzena, kadmija, niklja, svinca in selena so manjše od LOQ v vseh obravnavanih vodnih izlužkov porušenih vzorcev sanacijskega materiala. Za ostale parametre izmerjene vrednosti navajamo v Preglednici 5, skupaj z mejnimi vrednostmi parametrov izlužka za inertne odpadke (Uredba o odlagališčih odpadkov (2014)). Izmerjene vrednosti za alkaliteto kažejo na prisotnost karbonatnih $\left(\mathrm{HCO}_{3}, \mathrm{CO}_{3}^{2-}\right)$ zvrsti v vzorcih materialov s peščeno teksturo.

Iz Preglednice 5 je razvidno, da vrednosti parametrov kot so barij, baker, živo srebro, cink, kloridi, fluoridi in sulfati v vodnih izlužkih porušenih vzorcev, ne presegajo mejnih vrednosti parametrov izlužka za inertne odpadke. Mejne vrednosti pa so bile presežene v posameznih vzorcih izlužkov za 5 parametrov: krom $\mathrm{v}$ vzorcih V2G2 in V3G2, molibden v V2G2, fluorid v vzorcu V3G2, raztopljen organski ogljik v vzorcu V3G3 ter celotne raztopljene snovi v vzorcih V1G1, V1G5, V2G1 in V2G5.
Glede na vrste odpadkov, iz katerih so sanacijski materiali sestavljeni, so vir $\mathrm{Cr}$, $\mathrm{Cu}$ in Mo lahko odpadki iz predelave odpadne žlindre, predelave pepela in filtrskega prahu. Ob upoštevanju merilne negotovosti $( \pm 10 \%)$ izmed potencialno nevarnih kovin znatno izstopa samo Cr v enem vzorcu (V2G2).

Fluoridi predstavljajo reaktivno kemijsko zvrst, ki s sestavinami zemljine oz. vode, kot so kalcij in magnezij, tvorijo težko topne - kemijsko inertne spojine in tako ne prehajajo $\mathrm{z}$ vodo $\mathrm{v}$ širše okolje. Fluoridi pa $\mathrm{z}$ aluminijem in železom oziroma natrijem in kalijem tvorijo stabilne komplekse (Spletni vir, 2019d), ki so vodotopni. Možni izvor fluorida so lahko antropogeni - odpadni keramični materiali in vsi tisti odpadni materiali, ki nastanejo po uporabi naravnih mineralnih surovin (Ponsot in sod., 2013) lahko so pa tudi geogeni, saj glineni minerali med drugim vsebujejo tudi fluorid. Značilne vsebnosti fluorida v naravnih - neobremenjenih, geoloških materialih so do $100 \mathrm{mg} \mathrm{kg}^{-1} \mathrm{v}$ karbonatnih kamninah oz. do $600 \mathrm{mg} \mathrm{kg}^{-1} \mathrm{v}$ glinah (Turekian in sod., 1961).

Izmerjene vrednosti parametrov $\mathrm{v}$ vodnih izlužkih neporušenih sanacijskih materialov so prikazane $\mathrm{v}$ Preglednici 6, skupaj z mejnimi vrednostmi parametrov izlužka za inertne odpadke. Iz preglednice 6 je razvidno, 
Preglednica 6: Vrednosti parametrov $\left(\mathrm{mg} \mathrm{kg}^{-1} \mathrm{~s}\right.$. s.) v vodnih izlužkih neporušenih vzorcev sanacijskega materiala skupaj z mejnimi vrednostmi parametrov izlužka za inertne odpadke ter osnovnimi statistikami

Table 6: Values of parameters $\left(\mathrm{mg} \mathrm{kg}^{-1} \mathrm{~d} . \mathrm{m}\right.$.) in water leachates of undisturbed samples of rehabilitation material together with limit values of leachate parameters for inert waste and basic statistics

\begin{tabular}{|c|c|c|c|c|c|c|c|c|c|}
\hline Oznaka vzorca & V1 & $\mathrm{V} 2$ & V3 & $\mathrm{N}^{2}$ & Min. & Max. & $\mathrm{MN}^{3}$ & $\mathrm{MV}^{4}$ & $\mathrm{X}^{5}>\mathrm{MV}$ \\
\hline $\mathrm{Ba}$ & 25,2 & 0,123 & 0,143 & 3 & 0,123 & 25,2 & $\pm 10 \%$ & 20 & 1 \\
\hline $\mathrm{Cd}$ & $<0,008$ & $<0,004$ & 0,011 & 3 & $<0,004$ & 0,011 & $\pm 10 \%$ & 0,04 & 0 \\
\hline $\mathrm{Cr}$ & $<0,02$ & $<0,01$ & $<0,01$ & 3 & $<0,01$ & $<0,02$ & $\pm 10 \%$ & 0,50 & 0 \\
\hline $\mathrm{Cu}$ & 0,03 & 0,03 & 0,14 & 3 & 0,03 & 0,14 & $\pm 10 \%$ & 2 & 0 \\
\hline $\mathrm{Hg}$ & $<0,00001$ & 0,00061 & 0,00081 & 3 & $<0,00001$ & 0,00081 & $\pm 10 \%$ & 0,01 & 0 \\
\hline Mo & $<0,04$ & 0,126 & 0,496 & 3 & $<0,04$ & 0,496 & $\pm 10 \%$ & 0,50 & 0 \\
\hline $\mathrm{Pb}$ & 2,08 & $<0,05$ & 0,24 & 3 & $<0,05$ & 2,08 & $\pm 10 \%$ & 0,50 & 0 \\
\hline $\mathrm{Sb}$ & $<0,2$ & $<0,1$ & $<0,1$ & 3 & $<0,1$ & 0,01 & $\pm 10 \%$ & 0,06 & 0 \\
\hline $\mathrm{Zn}$ & 0,47 & 2,02 & 3,08 & 3 & 0,47 & 3,08 & $\pm 10 \%$ & 4 & 0 \\
\hline $\mathrm{Cl}^{-}$ & 26 & 175 & 144 & 3 & 26 & 175 & $\pm 15 \%$ & 800 & 0 \\
\hline $\mathrm{F}^{-}$ & $<2$ & 18,2 & 13,6 & 3 & $<2$ & 18,2 & $\pm 15 \%$ & 10 & 2 \\
\hline $\mathrm{SO}_{4}^{2-}$ & 50 & 267 & 251 & 3 & 50 & 267 & $\pm 15 \%$ & 1.000 & 0 \\
\hline DOC & 292 & 285 & 330 & 3 & 285 & 330 & $\pm 20 \%$ & 500 & 0 \\
\hline $\mathrm{CRS}^{1}$ & 11.600 & 1.940 & 2.990 & 3 & 1.940 & 11.600 & $\pm 10 \%$ & 4.000 & 1 \\
\hline Alkaliteta $\mathrm{pH} 4,5$ & 18,8 & 1,97 & 4,23 & 3 & 1,97 & 18,8 & $\pm 12 \%$ & I & / \\
\hline $\mathrm{Ca}$ & 3.680 & 27 & 93 & 3 & 27 & 3.680 & $\pm 10 \%$ & l & / \\
\hline $\mathrm{Mg}$ & 0,13 & 2,67 & 22,9 & 3 & 0,13 & 22,9 & $\pm 10 \%$ & / & / \\
\hline $\mathrm{K}$ & 1.260 & 32,5 & 34,6 & 3 & 32,5 & 1260 & $\pm 10 \%$ & / & / \\
\hline $\mathrm{P}$ & $<0,2$ & $<0,1$ & 1 & 3 & $<0,1$ & 1 & $\pm 10 \%$ & / & / \\
\hline $\mathrm{Na}$ & 238 & 675 & 923 & 3 & 238 & 923 & $\pm 10 \%$ & I & I \\
\hline B & $<0,2$ & 0,73 & 1,53 & 3 & $<0,2$ & 1,53 & $\pm 10 \%$ & / & I \\
\hline
\end{tabular}

${ }^{1}$ Celotne raztopljene snovi; 2 Število analiziranih vzorcev; ${ }^{3}$ Merilna negotovost analitska metode; ${ }^{4}$ Mejna vrednost parametrov izlužka za inertne odpadke (Uredba o odlagališčih odpadkov (2014)); ${ }^{5}$ Število vzorcev nad mejno vrednostjo

da vrednosti parametrov, kot so kadmij, krom, baker, živo srebro, molibden, svinec, antimon, cink, kloridi, sulfati in raztopljene organske snovi v vodnih izlužkih neporušenih vzorcev, ne presegajo mejnih vrednosti parametrov izlužka za inertne odpadke. Mejne vrednosti pa so presežene v posameznih vzorcih izlužkov za 2 parametra: barij v vzorcu V1 in fluorid v vzorcih V2 in V3. Znatno so povečane celotne raztopljene snovi, in sicer v vzorcu V1 (11.600 $\mathrm{mg} \mathrm{kg}^{-1}$ s. s.). Med raztopljenimi snovmi pa je pomemben tudi delež snovi kloridov in sulfatov natrija in kalija. Na osnovi izmerjenih vrednosti kemijsko sestavo raztopljenih snovi v vodnem izlužku, ni možno neposredno povezati s kemijsko sestavo preiskovanih materialov. Možnost vpliva vgrajenih sanacijskih materialov na drugih lokacijah ni izključena. Vsebnosti neraztopljenih snovi, praviloma so to netopne snovi kombinacij $\mathrm{Ca}, \mathrm{Mg}, \mathrm{Ba}$ in $\mathrm{Sr}$ na kationski strani ter karbonatov, sulfatov, tudi fluoridov, na anionski strani, so skladne s povečanimi vsebnostmi $\mathrm{Ca}, \mathrm{K}$ in vrednosti alkalitete $\mathrm{v}$ vzorcu $\mathrm{V} 1$.

Rezultati kažejo, da so že v porušenih vzorcih sanacijskega materiala, ki predstavljajo stanje materiala pred vgradnjo, kovine slabo vodotopne. Podobne rezultate kažejo tudi izmerjene vrednosti kovin v neporušenih vzorcih, ki pa predstavljajo dejansko stanje $\mathrm{v}$ naravi. Zato ocenjujemo, da so iz vidika možnega prehajanja kovin iz sanacijskega materiala $\mathrm{v}$ vodo, materiali inertni. Da so kovine slabo vodotopne v materialih, ki jih sestavljata livarski pesek ali elektrofiltrski pepel, za katere sklepamo, da so izvor kovin v sanacijskih materialih, ugotavljata tudi Kočevar (1991a) in Bożym (2017). Kočevar (1991a) tudi ugotavlja, da razen povečanih vrednosti $\mathrm{pH}$ v izlužkih, ni kratkoročnega vpliva na vodo.

Vodotopne frakcije kovin so najšibkejše vezane frakcije kovin in kot take zelo mobilne in potencialno dostopne za bioto. $Z$ vodotopnimi frakcijami lahko oce- 
nimo delež celotnih kovin, ki se izlužuje v talno porno vodo in je tako na voljo za privzem $\mathrm{v}$ rastline ali pa potuje s tokom $\mathrm{v}$ podzemno vodo (Pirrone and Mahaffey, 2005; Ogundiran in Osibanjo, 2009; Nwoko in sod., 2018). Raziskave namreč kažejo, da je na s kovinami obremenjenem območju potrebno za rekultivacijo vrhnje plasti v kmetijske namene pazljivo izbrati vrsto gojenih rastlin, pri čemer naj bi bile najbolj primerne rastline, katerih plodovi so namenjeni za prehrano, veliko manj pa listnate rastline in rastline $\mathrm{z}$ gomolji. $\mathrm{V}$ primeru, gojenja rastlin, ki kopičijo večje količine kovin, pa je nujno potrebno rastline dolgoročno

Preglednica 7: Primerjava izmerjenih celokupnih vrednosti $\left(\mathrm{mg} \mathrm{kg}^{-1} \mathrm{~s}\right.$. s.) anorganskih snovi v vzorcih okoliških površinskih tal s povprečnimi vrednostmi v slovenskih tleh ter mejno, opozorilno in kritično vrednostjo

Table 7: Comparison of measured total values $\left(\mathrm{mg} \mathrm{kg}^{-1} \mathrm{~d}\right.$. m.) of inorganic substances in surrounding surface soil samples to average values in Slovenian soil and limit, warning and critical values

\begin{tabular}{|c|c|c|c|c|c|c|c|c|c|}
\hline Parameter & $\mathrm{T} 1$ & $\mathrm{~T} 2$ & $\mathrm{MN}^{1}$ & $\begin{array}{l}\text { Povprečne } \\
\text { vrednosti v } \\
\text { slovenskih } \\
\text { tleh }(0-10 \\
\mathrm{cm})^{2}\end{array}$ & $\begin{array}{l}\text { Faktor obo- } \\
\text { gatitve } \mathrm{T} 1\end{array}$ & $\begin{array}{l}\text { Faktor obo- } \\
\text { gatitve T2 }\end{array}$ & $\begin{array}{l}\text { Mejna vred- } \\
\text { nost }^{3}\end{array}$ & $\begin{array}{l}\text { Opozorilna } \\
\text { vrednost }^{3}\end{array}$ & $\begin{array}{l}\text { Kritična } \\
\text { vrednost }^{3}\end{array}$ \\
\hline $\mathrm{Al}$ & 16.400 & 17.100 & $\pm 20 \%$ & 19.000 & 0,9 & 0,9 & I & / & / \\
\hline As & 4,86 & 3,41 & $\pm 20 \%$ & 13 & 0,4 & 0,3 & 20 & 30 & 50 \\
\hline B & 5,6 & 8 & $\pm 20 \%$ & 2,8 & 2,0 & 2,9 & I & / & / \\
\hline $\mathrm{Ba}$ & 60,8 & 55,3 & $\pm 20 \%$ & 83 & 0,7 & 0,7 & / & / & / \\
\hline $\mathrm{Be}$ & 0,725 & 0,795 & $\pm 20 \%$ & 1 & 0,7 & 0,8 & I & I & I \\
\hline $\mathrm{Ca}$ & 3.410 & 14.100 & $\pm 20 \%$ & 20.000 & 0,2 & 0,7 & I & / & I \\
\hline $\mathrm{Cr}$ & 22,4 & 24,7 & $\pm 20 \%$ & 38 & 0,6 & 0,7 & 100 & 150 & 380 \\
\hline Co & 10,1 & 8,30 & $\pm 20 \%$ & 15 & 0,7 & 0,6 & 20 & 50 & 240 \\
\hline $\mathrm{Cu}$ & 12,6 & 8,8 & $\pm 20 \%$ & 25 & 0,5 & 0,4 & 60 & 100 & 300 \\
\hline $\mathrm{Fe}$ & 21.000 & 18.300 & $\pm 20 \%$ & 28.000 & 0,8 & 0,7 & / & / & I \\
\hline $\mathrm{Li}$ & 19,2 & 21,9 & $\pm 20 \%$ & 20 & 1,0 & 1,1 & I & I & I \\
\hline $\mathrm{Mg}$ & 2.750 & 3.330 & $\pm 20 \%$ & 9.800 & 0,3 & 0,3 & I & I & / \\
\hline $\mathrm{Mn}$ & 652 & 115 & $\pm 20 \%$ & 960 & 0,7 & 0,1 & I & / & I \\
\hline $\mathrm{Hg}$ & 0,064 & 0,051 & $\pm 20 \%$ & 0,17 & 0,4 & 0,3 & 0,8 & 2 & 10 \\
\hline Mo & 0,57 & $<0,4$ & $\pm 20 \%$ & 1,4 & 0,4 & / & 10 & 40 & 200 \\
\hline $\mathrm{Ni}$ & 18,2 & 21,4 & $\pm 20 \%$ & 34 & 0,5 & 0,6 & 50 & 70 & 210 \\
\hline $\mathrm{P}$ & 676 & 354 & $\pm 20 \%$ & 630 & 1,1 & 0,6 & I & I & I \\
\hline K & 1.410 & 1.520 & $\pm 20 \%$ & 1.300 & 1,1 & 1,2 & I & I & I \\
\hline $\mathrm{Si}$ & 229 & 223 & $\pm 20 \%$ & I & I & / & / & / & / \\
\hline $\mathrm{Na}$ & 40 & 54 & $\pm 20 \%$ & 79 & 0,5 & 0,7 & I & I & / \\
\hline $\mathrm{Sr}$ & 10,9 & 21,7 & $\pm 20 \%$ & 30 & 0,4 & 0,7 & I & I & I \\
\hline S & 434 & 540 & $\pm 20 \%$ & 430 & 1,0 & 1,3 & I & I & I \\
\hline $\mathrm{Ti}$ & 109 & 100 & $\pm 20 \%$ & 120 & 0,9 & 0,8 & I & I & / \\
\hline V & 25,6 & 25,2 & $\pm 20 \%$ & 49 & 0,5 & 0,5 & I & / & I \\
\hline $\mathrm{Pb}$ & 24,9 & 16,5 & $\pm 20 \%$ & 40 & 0,6 & 0,4 & 85 & 100 & 530 \\
\hline $\mathrm{Zn}$ & 50,7 & 38,9 & $\pm 20 \%$ & 83 & 0,6 & 0,5 & 200 & 300 & 720 \\
\hline $\mathrm{NO}_{2}$ & 6,02 & $<5$ & I & I & I & I & I & I & / \\
\hline $\mathrm{NO}_{2}-\mathrm{N}$ & 1,36 & $<1,5$ & I & I & I & I & I & I & I \\
\hline $\mathrm{SO}_{4}$ & 26,7 & 90,3 & / & / & I & I & 1 & I & 1 \\
\hline
\end{tabular}

${ }^{1}$ Merilna negotovost analitska metode; ${ }^{2}$ Gosar in sod. (2019); ${ }^{3}$ Uredba o mejnih, opozorilnih in kritičnih imisijskih vrednostih nevarnih snovi $\mathrm{v}$ tleh (1996) 
nadzorovati (Kočevar, 1991b v Pogačnik, 2007)). Različne vrste dreves pa so sposobne shraniti enako ali večjo količino težkih kovin kot zelnate rastline. Za dekontaminacijo onesnaženih tal so posebej primerna hitro rastoča drevesa z globokim koreninskim sistemom (topol in vrba), saj ne potrebujejo pogoste obdelave (Di Lonardo in sod., 2011, Zacchini in sod., 2011).

\subsection{OKOLIŠKA POVRŠINSKA TLA}

\subsubsection{Celokupne vrednosti anorganskih snovi}

V Preglednici 7 so navedene izmerjene celokupne vsebnosti anorganskih snovi v vzorcih okoliških površinskih tal skupaj z mejnimi, opozorilnimi in kritičnimi vrednostmi nevarnih snovi $\mathrm{v}$ tleh (Uredba o mejnih, opozorilnih in kritičnih imisijskih vrednostih nevarnih snovi v tleh (1996)) ter povprečnimi vrednostmi elementov v slovenskih tleh (Gosar in sod., 2019).

Vsebnosti kovin so pod mejnimi, opozorilnimi in kritičnimi vrednostmi. Glede na primerjavo s povprečnimi vsebnostmi elementov v slovenskih tleh so izmerjene vrednosti elementov $\mathrm{v}$ vzorcih površinskih tal $\mathrm{T} 1$ in T2 manjše ali istega reda velikosti. Faktor obogatitve kaže, da je samo B zanemarljivo povečan $(2 \times \mathrm{v}$ T1 oz. 2,9 $\times \mathrm{v}$ T2). $\mathrm{Br}, \mathrm{Cl}, \mathrm{F}$ in $\mathrm{NO}_{3}$ oz. $\mathrm{NO}_{3}-\mathrm{N}$ so manjši od LOQ v obeh obravnavanih vzorcih tal. Vsebnost rastlinam dostopnega oz. mobilnega nitratnega dušika $\mathrm{NO}_{2}-\mathrm{N}$ je bila zaznana v vzorcu T1 in je majhna $\left(1,36 \mathrm{mg} \mathrm{kg}^{-1}\right)$. Sulfat v tleh, ki predstavlja rastlinam dostopno oz. mobilno obliko, je bil zaznan v obeh obravnavanih vzorcih $(26,7 \mathrm{mg}$ $\mathrm{kg}^{-1} \mathrm{v}$ T1 in 90,3 $\mathrm{mg} \mathrm{kg}^{-1} \mathrm{v}$ T2).

\subsubsection{Celokupne vrednosti organskih snovi}

Celotni organski ogljik (TOC) v vzorcu T1 znaša 2,8 \% s. s. in v vzorcu T2 2,73 \% s. s., kar pomeni da so tla srednje humozna (Zupan in sod., 2008). Vrednosti mineralnih olj v vzorcu T1 (41 $\mathrm{mg} \mathrm{kg}^{-1}$ s. s.) in v vzorcu T2 (43 $\mathrm{mg} \mathrm{kg}^{-1} \mathrm{~s}$. s), so pod mejno vrednostjo (50 $\mathrm{mg} \mathrm{kg}^{-1} \mathrm{~s}$. s.) (Uredba o mejnih, opozorilnih in kritičnih imisijskih vrednostih nevarnih snovi v tleh 1996). Vrednosti BTEX-ov, PCB-jev, PAH-ov, formaldehidov, fenolov, krezolov, naftolov in fenolnega indeksa so manjši od LOQ v obeh obravnavanih vzorcih tal in s tem pod mejnimi, opozorilnimi in kritičnimi vrednostmi.

Rezultati analiz kažejo, da so okoliška površinska tla v dobrem stanju, saj se vsebnosti vseh izmerjenih parametrov nahajajo pod mejnimi, opozorilnimi in kritičnimi vrednostmi. Prav tako je ugotovljeno, da vpliv emisij iz zraka zaradi vgrajevanja sanacijskega materiala na okoliška površinska tla ni zaznan.

Odkop kremenovega peska na območju Drtije je glede na rudarski načrt (Vajović in sod., 2016) segal tudi južno od obravnavanega območja, ki pa je sedaj že saniran in rekultiviran ter zatravljen. Sklepamo, da vzorčno mesto T2 predstavlja vrhnjo plast že rekultiviranega dela odkopa Drtija. Okoliška površinska tla, ki se nahajajo $\mathrm{v}$ neposredni bližini jugovzhodno od obravnavanega območja in vzorca T2, je preiskovala tudi Škornik Grdina (2016). Omenjena avtorica je ugotavljala osnovne lastnosti tal že rekultivirane površine kopa Drtije, ki je bil saniran $z$ umetno pripravljeno zemljino. Slednja se po njenih raziskavah pojavlja na $40 \mathrm{~cm}$ globine. Ugotovila je, da sicer tla niso zadovoljivo preskrbljena s fosforjem in kalijem, vendar pa so razmere za mikrobno aktivnost in dostopnost hranil optimalne in vsebnost organske snovi je dobra. Škornik Grdina (2006) sklepa, da je obravnavano rekultivirano zemljišče primerno za kmetijsko rabo, vendar pa bi kmetijsko zemljišče lahko izboljšali s sajenjem primerne travne ruše in ustreznim gnojilnim načrtom, ki bi izboljšal preskrbljenost tal s fosforjem, kalijem in organsko snovjo. S tem bi se izboljšale razmere za rast in razvoj rastlin.

\subsection{IZCEDNE VODE}

\subsubsection{Terenski parametri}

Iz preglednice 8 je razvidno, da je za vzorec izcedne vode VO značilen majhen pretok vode $\left(0,051 \mathrm{~s}^{-1}\right)$, zaradi česar je reprezentativnost rezultatov meritev za vrsto parametrov, kot na primer neraztopljene snovi, biološka in kemijska poraba kisika, povsem neprimerna.

Izcedna voda iz sanacijskega materiala ima $\mathrm{pH}$ vrednost 7,37 in je v okviru sprejemljivih vrednosti za vode naravnega okolja $(6,5-8,5)$. Električna prevodnost (EC), kot merilo raztopljenih ionsko aktivnih snovi, je poveča-

Preglednica 8: Merjeni terenski parametri pri vzorčenju izcedne vode

Table 8: Measured field parameters of leachate sampling

\begin{tabular}{llllllll}
\hline Oznaka vzorca & Pretok & $\mathrm{T}$ & $\mathrm{EC}$ & $\mathrm{pH}$ & $\mathrm{ORP}$ & Razt. kisik & Razt. kisik \\
\hline & $\mathrm{L} \mathrm{s}-1$ & ${ }^{\circ} \mathrm{C}$ & $\mu \mathrm{S} \mathrm{cm}^{-1}$ & $/$ & $\mathrm{mV}$ & $\mathrm{mg} \mathrm{O}_{2} \mathrm{l}^{-1}$ & $\% \mathrm{O}_{2}$ \\
$\mathrm{VO}$ & 0,05 & 11,2 & 3.910 & 7,37 & -106 & 0,84 & 7,6 \\
\hline
\end{tabular}


na $\left(3910 \mu \mathrm{S} \mathrm{cm}^{-1}\right)$. Za primerjavo znaša mejna vrednost za pitno vodo, določena z $2500 \mu \mathrm{S} \mathrm{cm}{ }^{-1}$ (Pravilnik o pitni vodi (2004)). Izmerjena vsebnost raztopljenega kisika je $0,84 \mathrm{mg} \mathrm{O}_{2} \mathrm{l}^{-1}$ ter oksidacijsko-redukcijskega potenciala $-106 \mathrm{mV}$, kar pomeni, da so razmere redukcijske.

\subsubsection{Anorganske snovi}

V preglednici 9 so predstavljeni rezultati meritev anorganskih parametrov v izcedni vodi. Iz preglednice je razvidno, da je izcedna voda obremenjena $z$ anorganskimi snovmi, ki so v vodi dobro topne. Od osnovnih komponent vode, ki določajo mineralizacijo vode $[\mathrm{Na}$,
$\mathrm{K}, \mathrm{Ca}, \mathrm{Mg}] / /\left[\mathrm{HCO}_{3}, \mathrm{Cl}, \mathrm{SO}_{4}\right]$, so izmerjene povečane vsebnosti kalija in natrija, ki sta $\mathrm{v}$ ionskem ravnotežju s povečanimi vsebnostmi klorida in sulfata. Navedene sestavine vode tudi določajo povečane vrednosti električne prevodnosti. Glede na izmerjene vsebnosti kalcija (270 $\left.\mathrm{mg} \mathrm{l}^{-1}\right)$ ter magnezija (35 $\left.\mathrm{mg} \mathrm{l}^{-1}\right)$, izmerjene vsebnosti $\mathrm{Na}, \mathrm{K}$ ter $\mathrm{Cl}$ in $\mathrm{SO}_{4}$ presegajo pričakovana naravna razmerja $\mathrm{v}$ podzemni in površinski vodi navedenih elementov (Mezga, 2014). Zato so izmerjene vsebnosti $\mathrm{Na}, \mathrm{K}$ ter $\mathrm{Cl}$ in $\mathrm{SO}_{4}$ ocenjene za dodatno obremenitev izcedne vode. Enake ugotovitve nakazujejo tudi rezultati analiz izlužka neporušenega vzorca V1 (Preglednica 6) in rezultati izvedenih preiskav izlužkov porušenih vzorcev V1G5, V2G1 in V2G3 (Pregledni-

Preglednica 9: Vsebnosti anorganskih in nekaterih organskih parametrov $\left(\mathrm{mg} \mathrm{l}^{-1}\right) \mathrm{v}$ izcedni vodi na obravnavanem območju Table 9: Content of inorganic and some organic parameters $\left(\mathrm{mg} \mathrm{l}^{-1}\right)$ in the leachate in the study area

\begin{tabular}{|c|c|c|c|c|c|}
\hline Parameter & VO & $\mathrm{MN}^{1}$ & Mejna vrednost ${ }^{2}$ & Mejna vrednost ${ }^{3}$ & Mejna vrednost ${ }^{4}$ \\
\hline AOX & 0,03 & $\pm 32 \%$ & 0,5 & I & I \\
\hline TOC & 712 & $\pm 20 \%$ & I & 30 & I \\
\hline $\mathrm{NH}_{4}$ & 44 & $\pm 15 \%$ & 50 & l & 0,5 \\
\hline BPK5 & 1300 & $\pm 15 \%$ & 30 & I & I \\
\hline KPK & 2220 & $\pm 15 \%$ & 300 & I & I \\
\hline $\mathrm{Cl}$ & 273 & $\pm 15 \%$ & I & 1 & 250 \\
\hline $\mathrm{F}$ & 1,35 & $\pm 15 \%$ & I & 10 & 1,5 \\
\hline $\mathrm{P}\left(\mathrm{P}_{2} \mathrm{O}_{5}\right)$ & 1,15 & $\pm 20 \%$ & I & 2,87 & I \\
\hline $\mathrm{SO}_{4}^{2-}$ & 914 & $\pm 15 \%$ & I & I & 250 \\
\hline $\mathrm{N}_{\text {CELOK. }}$ & 48 & $\pm 30 \%$ & I & I & I \\
\hline $\mathrm{P}_{\text {СЕLОK. }}$ & 0,50 & $\pm 20 \%$ & 2 & 2 & I \\
\hline $\mathrm{PO}_{4}^{3-}$ СЕLOK. & 1,54 & $\pm 20 \%$ & I & I & I \\
\hline $\mathrm{Ca}$ & 270 & $\pm 10 \%$ & l & I & I \\
\hline $\mathrm{Mg}$ & 35 & $\pm 10 \%$ & I & I & I \\
\hline K & 93 & $\pm 10 \%$ & I & I & I \\
\hline $\mathrm{Na}$ & 1050 & $\pm 10 \%$ & I & I & 200 \\
\hline As & $<0,01$ & $\pm 10 \%$ & l & 0,1 & 0,01 \\
\hline B & 0,565 & $\pm 10 \%$ & I & 1,0 & 1,0 \\
\hline $\mathrm{Cr}-_{\text {SKUPNI }}$ & $<0,002$ & $\pm 10 \%$ & 0,5 & 0,5 & 0,05 \\
\hline $\mathrm{Cu}$ & $<0,002$ & $\pm 10 \%$ & 0,5 & 0,5 & 2,0 \\
\hline $\mathrm{Ni}$ & 0,0154 & $\pm 10 \%$ & 0,5 & 0,5 & 0,02 \\
\hline $\mathrm{Pb}$ & $<0,01$ & $\pm 10 \%$ & 0,5 & 0,5 & 0,01 \\
\hline $\mathrm{Hg}$ & $<0,01$ & $\pm 10 \%$ & 0,01 & 0,005 & 0,001 \\
\hline $\mathrm{Cd}$ & $<0,0008$ & $\pm 10 \%$ & 0,1 & 0,025 & 0,005 \\
\hline $\mathrm{Zn}$ & 0,0054 & $\pm 10 \%$ & 2 & 2 & I \\
\hline Fenolni indeks & 1,26 & $\pm 20 \%$ & l & 0,1 & I \\
\hline Formaldehid & 6,11 & $\pm 20 \%$ & I & 13 & 1 \\
\hline
\end{tabular}

${ }^{1}$ Merilna negotovost analitska metode; ${ }^{2}$ Uredba o emisiji snovi pri odvajanju izcedne vode iz odlagališč odpadkov (2008); ${ }^{3}$ Uredba o emisiji snovi in toplote pri odvajanju odpadnih voda v vode in javno kanalizacijo (2012); ${ }^{4}$ Pravilnik o pitni vodi (2004); 
ca 5), kjer je ugotovljeno, da so izstopajoče vsebnosti sulfatov prisotne tudi v izlužkih vzorcev sanacijskega materiala, vendar pa zaradi heterogenosti območja le-te ni možno neposredno povezati z lokacijami, kjer je bil odvzet vzorec izcedne vode. Izvor sulfatov so lahko odpadki iz predelave papirniškega mulja in pepela (Goñi in sod., 2014).

Izmerjeni sta tudi povečani vrednosti za biološko porabo kisika (BPK5) $1300 \mathrm{mg} \mathrm{l}^{-1} \mathrm{O}_{2}$ in kemijsko porabo kisika (KPK) $2220 \mathrm{mg} \mathrm{l}^{-1} \mathrm{O}_{2}$. Posledica obremenitev so majhne vsebnosti kisika, kar pomeni, da so razmere ocenjene kot "pomanjkanje kisika«. Izmerjene vsebnosti amonija v vodi so povečane $\left(44 \mathrm{mg} \mathrm{l}^{-1} \mathrm{NH}_{4}\right)$.

Izcedna voda vsebuje fluorid $\left(1,35 \mathrm{mg} \mathrm{l}^{-1}\right)$, ki pa ne presega mejne vrednosti določene $\mathrm{z}$ Uredbo o emisiji snovi in toplote pri odvajanju odpadnih voda $\mathrm{v}$ vode in javno kanalizacijo (2012). Povečane vsebnosti fluoridov so bile ugotovljene tudi v vodnih izlužkih vzorcev sanacijskih materialov (Preglednici 5 in 6). Možni izvor fluorida so odpadni keramični materiali in vsi tisti odpadni materiali, ki nastanejo po uporabi naravnih mineralnih surovin (Ponsot in sod., 2013). Ne glede na mejno vrednost, se izmerjene vsebnosti fluorida ne ocenjujejo za pomembne, saj je fluorid reaktivna snov, ki se v naravnem okolju s kalcijem, magnezijem praviloma veže $\mathrm{v}$ težko topne fluoride in tako ne prehaja naprej v okolje. S sestavinami kot so železo in aluminij oziroma kalij in natrij pa tvori kemijsko stabilne komplekse, ki pa so vodotopni.

Izmerjene vsebnosti težkih kovin in arzena so $\mathrm{v}$ izcedni vodi na koncentracijskem nivoju spodnje meje določanja (LOQ) (Preglednica 9), kar je pričakovano, saj so že analize vodnih izlužkov pokazale, da so te kovine slabo topne v vodi in s tem tudi slabo mobilne.

Obremenitve izcedne vode $\mathrm{z}$ nenevarnimi anorganskimi snovmi ne predstavljajo pomembnega tveganja za širjenje morebitnega onesnaženja v okolje. $\mathrm{Na}$ obravnavanem območju prevladuje površinski odtok padavin, le majhen delež se jih infiltrira v tla, kar nakazuje tudi majhen pretok izcedne vode in redukcijske razmere $\mathrm{v}$ času vzorčenja. Zaradi tega se morebitno onesnaženje, že na majhnih razdaljah od območja sanacije razredči, ko pride $\mathrm{v}$ stik $\mathrm{z}$ neobremenjeno talno vodo iz okolice ali s padavinami. Ob tem pa se lahko spremenijo tudi redoksne razmere, ki narekujejo usodo posameznih onesnaževal v vodi. Velik delež k možnosti širjenja onesnaženja $\mathrm{v}$ okolje pa narekujejo tudi procesi naravnih zadrževalnih sposobnosti.

\subsubsection{Organske snovi}

Iz preglednice 9 je razvidno, da izcedna voda vse- buje formaldehid $\left(6,11 \mathrm{mg} \mathrm{l}^{-1}\right)$, ki pa ne presega mejne vrednosti določene $z$ Uredbo o emisiji snovi in toplote pri odvajanju odpadnih voda $\mathrm{v}$ vode in javno kanalizacijo (2012), ki znaša $13 \mathrm{mg} \mathrm{l}^{-1}$. Ne glede na mejno vrednost, predstavlja formaldehid zelo mobilno snov (porazdelitveni koeficient na organski $\mathrm{C}\left(\mathrm{K}_{\mathrm{OC}}\right)$ znaša 8 ), za katero se ne pričakuje, da se bo vezala na suspendirane snovi v vodi ali na sediment. Nedvomno pa je pričakovana biorazgradnja, v obsegu do $90 \% \mathrm{v}$ dveh tednih (spletni vir, 2019a). V razmerah brezvetrja obstaja možnost, da se prisotnost formaldehida $\mathrm{v}$ vodi zazna tudi $\mathrm{z}$ vonjem, prag zaznavanja je okrog $0,83 \mathrm{mg} \mathrm{l}^{-1}$ (spletni vir, 2019b). Izmerjena vsebnost fenola merjenega in izraženega kot fenolni indeks, kar pomeni skupino fenolnih snovi, znaša $1,26 \mathrm{mg} \mathrm{l}^{-1}$. Praviloma se fenol oz. fenolne snovi v vodnih tokovih vežejo na neraztopljene, predvsem organske delce in na delce sedimenta, biološka razgradnja tako adsorbiranih fenolnih snovi poteče v nekaj dneh, odvisno od dinamike vodnega toka. Formaldehid in fenol sta tudi naravno prisotna $\mathrm{v}$ rastlinah (spletni vir, 2019c). Ocenjujemo, da kljub temu, da gre pri obeh snoveh za mobilno snov, zaradi relativno hitre biološke razgradljivosti nista škodljiva za okolje.

Izmerjene vsebnosti organskih snovi iz sklopov BTEX, PAH, kloriranih derivatov fenola in mineralnih olj (C10-C40) so v izcedni vodi na koncentracijskem nivoju spodnje meje določanja (LOQ).

\section{SKLEPI}

V prispevku smo opredelili kemično sestavo že vgrajenega sanacijskega materiala, ki je namenjen za tehnično sanacijo opuščenega peskokopa, okoliških površinskih tal in izcedne vode. Na osnovi njihove medsebojne povezave smo opredelili potencialni vpliv sanacijskega materiala na bodočo rekultivacijo.

Rezultati študije kažejo, da sanacijski materiali v obliki gradbenih kompozitov, vsebujejo znatne količine kovin $(\mathrm{Cd}, \mathrm{Cr}, \mathrm{Cu}, \mathrm{Ni}, \mathrm{Pb}, \mathrm{Zn})$, ki pa so v danih razmerah slabo vodotopne, kar nakazujejo tudi izmerjene vrednosti le-teh $\mathrm{v}$ vodnih izlužkih in izcedni vodi. $\mathrm{V}$ izcedni vodi se kovine pojavljajo na koncentracijskem nivoju spodnje meje določanja (LOQ). Zato ocenjujemo, da kovine niso na voljo za privzem $\mathrm{v}$ rastline ali za prenos s tokom v podzemno vodo oz. $\mathrm{v}$ okolje.

Obremenitve z nenevarnimi anorganskimi snovmi $\left(\mathrm{Ca}, \mathrm{Mg}, \mathrm{Na}, \mathrm{K}, \mathrm{SO}_{4}^{-}, \mathrm{F}\right.$ ) so bile ugotovljene $\mathrm{v}$ vodnih izlužkih sanacijskih materialov in izcedni vodi, ki pa ne predstavljajo pomembnega tveganja za prenos $\mathrm{v}$ rastline v primerjavi s kovinami. Od organskih snovi pa je določena prisotnost fenola in formaldehida. Ocenjujemo, da zaradi njune relativno velike mobilnosti in hitre 
biološke razgradljivosti nista škodljiva za okolje, prav tako pa se pojavljata tudi že v rastlinah kot naravni sestavini.

S preiskavami tal je ugotovljeno, da emisije iz zraka zaradi vgrajevanja sanacijskega materiala ne vplivajo na okoliška površinska tla. Slednja so glede na zakonodajne smernice $\mathrm{v}$ dobrem stanju.

Glede na smernice za kovine, ki jih predpisuje Uredba o mejnih, opozorilnih in kritičnih imisijskih vrednostih nevarnih snovi v tleh (1996) sanacijski materiali (gradbeni kompoiti) zaradi potencialnih škodljivih učinkov ali vplivov na človeka in okolje niso primerni za pridelavo rastlin, namenjenih prehrani ljudi ali živali ter za zadrževanje ali filtriranje vode. Ob upoštevanju, da bo po končni tehnični sanaciji površina zapolnjena s plastmi gline in humusa ter zatravljena ali pogozdena (rekultivacija vrhnje plasti), oziroma da bo odtekanje padavin iz saniranega območja pretežno površinsko, vpliv že vgrajenih sanacijskih materialov na rekultivirana tla ni pričakovan. Iz previdnostnega načela je najbolj smiselna rekultivacija $\mathrm{z}$ gozdom, predvsem topoli in vrbami, saj imajo globok koreninski sistem in so sposobni črpati težke kovine. V primeru kmetijske rabe bi bilo sprejemljivo pašništvo ali pridelava krme z vzpostavljenim dolgoročnim spremljanjem kakovosti tal in krme. Uporaba rekultiviranih površin za njivsko pridelavo hrane ni priporočljiva, saj bi z gnojenjem, oranjem in namakanjem lahko porušili obstoječe stanje sanacije, ki je izvedena na način, da stabilizira in imobilizira potencialne nevarne snovi (predvsem kovine) $\mathrm{v}$ materialih v podlagi.

\section{ZAHVALA}

Ta študija je bila financirana s strani Občine Moravče. Avtorici se zahvaljujeta podjetju Termit d. d. za vse podatke, ki so bili potrebni za izvedbo študije ter Civilni iniciativi Moravče za vse informacije v zvezi z okoliščinami na obravnavanem območju. Prav tako se avtorici zahvaljujeva trem recenzentom za vse konstruktivne pripombe, ki so pomagale $\mathrm{k}$ izboljšavi tega prispevka.

\section{VIRI}

Atlas okolja, (2019). Agencija RS za okolje. Spletni portal: »http://gis.arso.gov.si/atlasokolja/profile.aspx?id=Atlas_ Okolja_AXL@Arso«.

Barbuta, M., Bucur, R. D., Cimpeanu, S. M., Paraschiv, G., \& Bucur, D. (2015). Wastes in Building Materials Industry. Agroecology, 81.

Basu, M., Pande, M., Bhadoria, P. B. S., \& Mahapatra, S. C.
(2009). Potential fly-ash utilization in agriculture: a global review. Progress in Natural Science, 19(10), 1173-1186. https://doi.org/10.1016/j.pnsc.2008.12.006

Bavec, Š., \& Gosar, M. (2016). Speciation, mobility and bioaccessibility of $\mathrm{Hg}$ in the polluted urban soil of Idrija (Slovenia). Geoderma, 273, 115-130. https://doi.org/10.1016/j. geoderma.2016.03.015

Bożym, M. (2017). The study of heavy metals leaching from waste foundry sands using a one-step extraction. In E3S Web of Conferences (Vol. 19, p. 02018). EDP Sciences.

Cerar, S., \& Bavec, Š. (2017). Analiza možnih vplivov sanacijskega materiala na območju nekdanjega odkopa Drtija v lasti družbe Termit d.d. na podzemne vode in površinske vode. Geološki zavod Slovenije, Ljubljana.

Collivignarelli, C., \& Sorlini, S. (2001). Optimisation of industrial wastes reuse as construction materials. Waste management \& research, 19(6), 539-544. https://doi. org/10.1177/0734242X0101900610

Chuang, K. H., Lu, C. H., Chen, J. C., \& Wey, M. Y. (2018). Reuse of bottom ash and fly ash from mechanical-bed and fluidized-bed municipal incinerators in manufacturing lightweight aggregates. Ceramics International, 44(11), 1269112696. https://doi.org/10.1016/j.ceramint.2018.04.070

Čop, J., Vidrih, M., \& Hacin, J. (2009). Influence of cutting regime and fertilizer application on the botanical composition, yield and nutritive value of herbage of wet grasslands in Central Europe. Grass and Forage Science, 64(4), 454465. https://doi.org/10.1111/j.1365-2494.2009.00713.x

De Matos, A. T., Fontes, M. P. F., Da Costa, L. M., \& Martinez, M. A. (2001). Mobility of heavy metals as related to soil chemical and mineralogical characteristics of Brazilian soils. Environmental pollution, 111(3), 429-435. https://doi. org/10.1016/S0269-7491(00)00088-9

Di Lonardo, S., Capuana, M., Arnetoli, M., Gabbrielli, R., \& Gonnelli, C. (2011). Exploring the metal phytoremediation potential of three Populus alba L. clones using an in vitro screening. Environmental Science and Pollution Research, 18(1), 82-90. https://doi.org/10.1007/s11356-0100354-7

Elliott, C., \& Udovč, A. (2005). Nature conservation and spatial planning in Slovenia: continuity in transition. Land use policy, 22(3), 265-276. https://doi.org/10.1016/j.landusepol.2004.02.002

Goñi, S., Frías, M., Vegas, I., \& García, R. (2014). Sodium sulphate effect on the mineralogy of ternary blended cements elaborated with activated paper sludge and fly ash. Construction and Building Materials, 54, 313-319. https:// doi.org/10.1016/j.conbuildmat.2013.12.052

Gosar, M., Šajn, R., Bavec, Š., Gaberšek, M., Pezdir, V., \& Miler, M. (2019). Geochemical background and threshold for 47 chemical elements in Slovenian topsoil $=$ Geokemično ozadje in zgornja meja naravne variabilnosti 47 kemičnih elementov v zgornji plasti tal Slovenije. Geologija, 62(1), 5-57. https://doi.org/ 10.5474/geologija.2019.001

Grčman, H., Velikonja-Bolta, Š., Vodnik, D., Kos, B., \& Leštan, D. (2001). EDTA enhanced heavy metal phytoextraction: metal accumulation, leaching and toxicity. Plant and Soil, 235(1),105-114.https://doi.org/10.1023/A:1011857303823

Grčman, H., \& Zupanc, V. (2018). Compensation for soil deg- 
radation after easement of agricultural land for a fixed period. Geodetski vestnik, 62(2), 235-248.

Griessler Bulc, T., \& Šajn Slak, A. (2009). Ecoremediations-a new concept in multifunctional ecosystem technologies for environmental protection. Desalination, 246(1-3), 2-10. https://doi.org/10.1016/j.desal.2008.03.039

John, V. M., \& Tinker, J. (1998). Recycling waste as building materials: an Internet database. Proceedings of the $C I B$ World Building Congress (pp. 611-616). https://www.irbnet.de/daten/iconda/CIB8640.pdf

Knez, M., \& Regent, T. (1993). Sanacija opuščenih gramoznic na Dravskem polju. Mišičev vodarski dan '93, 152-160.

Kočevar, H. 1991a. Vpliv elektrofiltrskega pepela na okolje : magistrska naloga, Ljubljana, Fakulteta za naravoslovje in tehnologijo, 124 str.

Kočevar, H., 1991b. Ugotavljanje vsebnosti biosencialnih in toksičnih prvin $v$ pepelu in tleh $v$ okolici deponije elektrofiltrskega pepela, ter ocena vpliva na rastline : raziskovalna naloga. Ljubljana, Fakulteta za naravoslovje in tehnologijo, Oddelek za montanistiko, 35 str.

Krümmelbein, J., Horn, R., Raab, T., Bens, O., \& Hüttl, R. F. (2010). Soil physical parameters of a recently established agricultural recultivation site after brown coal mining in Eastern Germany. Soil and Tillage Research, 111(1), 19-25. https://doi.org/10.1016/j.still.2010.08.006

Laner, D., Fellner, J., \& Brunner, P. H. (2011). Future landfill emissions and the effect of final cover installation -A case study. Waste management, 31(7), 1522-1531. https:/doi. org/10.1016/j.wasman.2011.02.022

Lapajne, V. (1993). Elaborat o kategorizaciji, klasifikaciji in izračunu rezerv kremenovega peska v ležiščih Moravške terciarne kadunje (Stanje 31. dec. 1992). Geološki zavod Ljubljana.

Marinko, M., Lapajne, T., Radelović, G., \& Ruglić, Z. (1975). Hidrogeološko poročilo o vodonosnosti peskov površinskega kopa »Drtja«Moravče«. Geološki zavod Slovenije, Ljubljana. Mauko Pranjić, A., Mladenović, A., Sever, K., Leban, J., Božič Cerar, A., Cotič, Z., Jurjavčič, P., Šprinzer, M. \& Leben, J. (2014). Promocija uporabe recikliranih gradbenih in industrijskih odpadkov v gradbeništvu. Poročilo za širšo javnost. Zavod za gradbeništvo Slovenije.

Mcnaughtan, T. J., \& Hoyt, H. E. (1958). U.S. Patent No. 2,856,381. Washington, DC: U.S. Patent and Trademark Office.

Mezga, K. (2014). Natural hydrochemical background and $d y$ namics of groundwater in Slovenia: PhD. thesis. Nova Gorica, Slovenia, $226 \mathrm{p}$.

MKGP. (2016). Ministrstvo za kmetijstvo, gozdarstvo in prehrano. Spletni portal: »http://rkg.gov.si/GERK/«.

Montanarella, L. (2017). Soil sealing and land take as global soil threat: the policy perspective. In: Gardi, C. (Ed.). Urban expansion, land cover and soil ecosystem services. Taylor \& Francis, 291-295.

Nwoko, T. p., Oluwasina, O. O., Abata, E., \& Ajai, O. O. (2108). Analysis of Heavy Metals in Soil from Residential and Mechanic Dumpsites. Journal of Environment Protection and Sustainable Development, 4(1), 7-15.

Ogundiran, M. B., \& Osibanjo, O. (2009). Mobility and speciation of heavy metals in soils impacted by hazardous waste.
Chemical Speciation \& Bioavailability, 21(2), 59-69. https:// doi.org/10.3184/095422909X449481

Pavlin, A., Horvat, B., \& Ducman, V. (2018). TERMIT`s Circular Economy. In: Bogataj, M., Kravanja, Z., Novak Pintarič, Z. (eds.). $1^{\text {st }}$ International conference on technologies \& business models for circular economy : conference proceedings, $5^{\text {th }}-7^{\text {th }}$ September 2018, Portorož, 89-100.

Pintar, M., Lobnik, F., \& Bohanec, B. (2010). Apel proti pozidavi kmetijskih zemljišč. Delo 52. Ljubljana.

Podlipnik, B. (2019). Uvodnik. Mineralne surovine, 15(1), 1223.

Pogačnik. M., 2007. Vplivi odlagališča elektrofiltrskega pepela Termoelektrarne Trbovlje na okolje : diplomsko delo. Univerza v Ljubljani, Filozofska fakulteta, Oddelek za geografijo. 85 str.

Ponsot, I., Falcone, R., \& Bernardo, E. (2013). Stabilization of fluorine-containing industrial waste by production of sintered glass-ceramics. Ceramics International, 39(6), 69076915. https://doi.org/10.1016/j.ceramint.2013.02.025

Pravilnik o pitni vodi (2004). Uradni list RS, št. 19/04, 35/04, 26/06, 92/06, 25/09, 74/15 in 51/17

Pirrone, N., \& Mahaffey, K. R. (2005). Where we stand on mercury pollution and its health effects on regional and global scales. In Dynamics of Mercury Pollution on Regional and Global Scales: (pp. 1-21). Springer, Boston, MA. https://doi.org/10.1007/0-387-24494-8_1

Rogelj, J., \& Karahodžič, M. (2004). Strokovne hidrogeološke podlage za pridobitev vodnega dovoljenja Vrtina V-1 Ples. Geološki zavod Slovenije, Ljubljana.

Ramesh, M., Kathic, K. S., Kathikeyan, T., \& Kumaravel., A (2014). Construction materials from industrial wastes - a review of current practices. International Journal of Environmental Reseacrh and Development, 4(4), 317-324.

Senegačnik, A., Burger, A. \& Štih, J. (2019). Stanje na področju mineralnih surovin v Sloveniji v letu 2018. Mineralne surovine, 15(1), 9-10.

Sharma, K.D., Kumar, P., Gough, L.P., \& Sanfilipo, J.R. (2004). Rehabilitation of a lignite mine-disturbed area in the Indian Desert. Land Degradation of Development, 15(2), 163-176. https://doi.org/10.1002/ldr.601

Spletni vir, 2019a: https:/toxnet.nlm.nih.gov/cgi-bin/sis/ search2/f?./temp/ j5fN2q:3 (citirano: 11.9.2019).

Spletni vir, 2019b: https://www.epa.gov/sites/production/ files/2016-09/documents/formaldehyde.pdf; https:// www.cdc.gov/niosh/docs/81-123/pdfs/0293.pdf (citirano: 11.9.2019)

Spletni vir, 2019c: https://toxnet.nlm.nih.gov/cgi-bin/sis/search2/f?./temp/ 41z0OK:3 (citirano: 11.9.2019)

Spletni vir, 2019d: https://pubchem.ncbi.nlm.nih.gov/compound/159692\#section=Computed-Properties (citirano: 11.11.2019)

Škornik Grdina, K. 2016. Lastnosti tal rekultiviranih zemljišč površinskih kopov: diplomsko delo $=$ Soil characteristics of recultivated mine areas : graduation thesis, Biotehniška fakulteta, Oddelek za agronomijo, 2428), Ljubljana, 51 pp.

Turekian, K. K., \& Wedepohl, K. H. (1961). Distribution of the elements in some major units of the earth's crust. Geological Society of America Bulletin, 72(2), 175-192. https://doi. org/10.1130/0016-7606(1961)72[175:DOTEIS]2.0.CO;2 
Uredba o emisiji snovi pri odvajanju izcedne vode iz odlagališč odpadkov (2008). Uradni list RS, št. 62/08

Uredba o emisiji snovi in toplote pri odvajanju odpadnih voda $\mathrm{v}$ vode in javno kanalizacijo (2012). Uradni list $R S$, št. 64/12, 64/14 in 98/15

Uredba o mejnih, opozorilnih in kritičnih imisijskih vrednostih nevarnih snovi v tleh (1996). Uradni list RS, št. 68/96 in $41 / 04-\mathrm{ZVO}-1$.

Uredba o obremenjevanju tal z vnašanjem odpadkov (2008). Uradni list RS, št. 34/08 in 61/11.

Uredba o odlagališčih odpadkov (2014). Uradni list $R S$, št. $10 / 14,54 / 15,36 / 16$ in 37/18.

Urbanc, M., \& Breg, M. (2005). Gravel plains in urban areas: gravel pits as an element of degraded landscapes. Acta geographica Slovenica, 45(2), 35-61. https://doi.org/10.3986/ AGS45202

Vajović, S., Hribar, T., Tori, M., Rojšek, M., Galuf, S., Čadež, F., Goleš, N., \& Filipič, M. (2016). Rudarski projekt za izvedbo pri končni sanaciji zahodnega dela odkopa Drtija z zaključnim izvajanjem del pri izkoriščanju kremenovega peska za področje Drtija - zahodni del. GR Investicije d.o.o., št. projekta: i-19/16-VS. Ljubljana.

Vrščaj, B. (2010). Varovanje kmetijskih zemljišč in racional- na raba prostora sta osnova trajnostnega razvoja. Kmečki glas, 67(4). Ljubljana.

Zacchini, M., Iori, V., Mugnozza, G. S., Pietrini, F., \& Massacci, A. (2011). Cadmium accumulation and tolerance in Populus nigra and Salix alba. Biologia Plantarum, 55(2), 383386. https://doi.org/10.1007/s10535-011-0060-4

Zakon o gradbenih proizvodih (2013). ZGPro-1, Uradni list $R S$, št. 82/13.

Zakon o rudarstvu (2010). ZRud-1, Uradni list RS, št. 14/14 uradno prečiščeno besedilo in $61 / 17$ - GZ.

Zupan, M., Grčman, H., Hodnik, A., Lobnik, F., Kralj, T., Rupreht, J., Šporar, M., Lapajne, S., Tič, I., Šijanec, V., Gogič, S., Mohorovičič, B., Ilc, R., \& Kobal, M. (2008). Raziskave onesnaženosti tal Slovenije. Agencija RS za okolje, Ljubljana, 63 pp.

Zupanc, V., \& Grčman, H. (2016). Hydraulic characteristics of recultivated surface mines. In: Čelkova, A. (ed.). Transport of water, chemicals and energy in the soil-plant-atmosphere system : Proceediings of peer-reviiewed contriibutiions, 23rd International Poster Day and Institute of Hydrology Open Day, 10th November 2016, Institute of Hydrology SAS, Dúbravská cesta 9, Bratislava, Slovak Republic. Bratislava: Ústav hydrológie Slovenskej akadémie vied., 285-289. 